\title{
Importance of seasonally resolved oceanic emissions for bromoform delivery from the tropical Indian Ocean and west Pacific to the stratosphere
}

\author{
Alina Fiehn' ${ }^{1,2, a}$, Birgit Quack ${ }^{2}$, Irene Stemmler ${ }^{3}$, Franziska Ziska ${ }^{4}$, and Kirstin Krüger ${ }^{1}$ \\ ${ }^{1}$ Meteorology and Oceanography Section, Department of Geosciences, University of Oslo, Oslo, Norway \\ ${ }^{2}$ GEOMAR Helmholtz Centre for Ocean Research Kiel, Kiel, Germany \\ ${ }^{3}$ Max Planck Institute for Meteorology, Hamburg, Germany \\ ${ }^{4}$ Deutscher Wetterdienst, Hamburg, Germany \\ ${ }^{a}$ now at: Deutsches Zentrum für Luft- und Raumfahrt, Oberpfaffenhofen, Germany
}

Correspondence: Kirstin Krüger (kkrueger@geo.uio.no)

Received: 28 January 2018 - Discussion started: 7 March 2018

Revised: 20 June 2018 - Accepted: 19 July 2018 - Published: 21 August 2018

\begin{abstract}
Oceanic very short-lived substances (VSLSs), such as bromoform $\left(\mathrm{CHBr}_{3}\right)$, contribute to stratospheric halogen loading and, thus, to ozone depletion. However, the amount, timing, and region of bromine delivery to the stratosphere through one of the main entrance gates, the Indian summer monsoon circulation, are still uncertain. In this study, we created two bromoform emission inventories with monthly resolution for the tropical Indian Ocean and west Pacific based on new in situ bromoform measurements and novel ocean biogeochemistry modeling. The mass transport and atmospheric mixing ratios of bromoform were modeled for the year 2014 with the particle dispersion model FLEXPART driven by ERA-Interim reanalysis. We compare results between two emission scenarios: (1) monthly averaged and (2) annually averaged emissions. Both simulations reproduce the atmospheric distribution of bromoform from ship- and aircraft-based observations in the boundary layer and upper troposphere above the Indian Ocean reasonably well.

Using monthly resolved emissions, the main oceanic source regions for the stratosphere include the Arabian Sea and Bay of Bengal in boreal summer and the tropical west Pacific Ocean in boreal winter. The main stratospheric injection in boreal summer occurs over the southern tip of India associated with the high local oceanic sources and strong convection of the summer monsoon. In boreal winter more bromoform is entrained over the west Pacific than over the Indian Ocean. The annually averaged stratospheric injection of bromoform is in the same range whether using monthly
\end{abstract}

averaged or annually averaged emissions in our Lagrangian calculations. However, monthly averaged emissions result in the highest mixing ratios within the Asian monsoon anticyclone in boreal summer and above the central Indian Ocean in boreal winter, while annually averaged emissions display a maximum above the west Indian Ocean in boreal spring. In the Asian summer monsoon anticyclone bromoform atmospheric mixing ratios vary by up to $50 \%$ between using monthly averaged and annually averaged oceanic emissions. Our results underline that the seasonal and regional stratospheric bromine injection from the tropical Indian Ocean and west Pacific critically depend on the seasonality and spatial distribution of the VSLS emissions.

\section{Introduction}

Halogenated very short-lived substances (VSLSs) contribute to the stratospheric halogen burden, take part in ozone depletion, and, thus, impact climate (Law et al., 2006). Brominated VSLSs are mainly of oceanic origin and their transport to the stratosphere depends on deep convection in the tropics. The contribution of oceanic VSLSs is estimated to be $10 \%-40 \%$ of the current, $\sim 20 \mathrm{ppt}$, total stratospheric bromine (Dorf et al., 2006; Montzka et al., 2010; Carpenter et al., 2014). Uncertainties mainly result from a lack of VSLS measurements in the tropical tropopause layer (TTL) tropospheric degradation and removal, transport processes, 
and especially from the spatial and temporal variability in halogenated VSLS emissions (Carpenter et al., 2014; Hossaini et al., 2016). In this study, we focus on the influence of seasonal emission variations.

Bromoform $\left(\mathrm{CHBr}_{3}\right)$ is one of the largest contributors to bromine from VSLSs $\left(\mathrm{Br}_{y}^{\mathrm{VSLS}}\right.$ ) in the stratosphere (Hossaini et al., 2012) due to its large oceanic emissions (Quack and Wallace, 2003), moderate tropospheric lifetime of 1517 days in the tropics (Carpenter et al., 2014), and because it contains three bromine atoms. The bromoform surface concentration in the ocean is spatially and temporally variable and depends on its chemical and biological production (Carpenter et al., 1999; Quack and Wallace, 2003). Enhanced emissions coincide with biologically active equatorial and coastal upwelling regions (Quack et al., 2007) and the distribution of macroalgae and anthropogenic sources along the coasts (Carpenter and Liss, 2000; Quack and Wallace, 2003). There are different approaches in creating global bromoform emission inventories. In the bottom-up approach, emissions are extrapolated from marine and atmospheric observations in different locations (Quack and Wallace, 2003; Butler et al., 2007; Palmer and Reason, 2009; Ziska et al., 2013). The topdown approach uses chemistry transport and chemistry climate models to infer possible emission distributions that reproduce observed atmospheric abundances of VSLSs (Warwick et al., 2006; Liang et al., 2010; Ordóñez et al., 2012). Recently, an ocean biogeochemical model simulated oceanic bromoform distributions and derived emissions (Stemmler et al., 2015) based on a marine production module (Hense and Quack, 2009) and observational atmospheric data (Ziska et al., 2013).

Overall, large differences between bromoform emission inventories exist. The bottom-up inventories (Ziska et al., 2013; Stemmler et al., 2015) estimate lower global bromoform emissions than the top-down inventories (Warwick et al., 2006; Liang et al., 2010; Ordóñez et al., 2012). The topdown emission inventories and the Ziska et al. (2013) inventory have been compared and evaluated by Hossaini et al. (2013). The observation-based bromoform emissions of Ziska et al. (2013) led to the best agreement with tropospheric measurements of atmospheric mixing ratios in the tropics. Some emission inventories represent climatological annual means (Warwick et al., 2006; Liang et al., 2010) and other inventories include a seasonality of emissions (Ordóñez et al., 2012; Ziska et al., 2013; Stemmler et al., 2015).

In the atmosphere, VSLSs are defined as having a lifetime shorter than half a year (Law et al., 2006). They degrade through photolysis or reaction with the hydroxyl radical $(\mathrm{OH})$ into soluble substances, which can then be washed out from the troposphere. Stratospheric delivery of VSLS is connected to fast and high-reaching convection and ascent of air masses through the TTL into the stratosphere (Gettelman et al., 2009), because their degradation occurs on similar timescales as the transport. The main regions of injection of tropospheric air masses into the stratosphere lie over the trop- ical west Pacific Ocean in boreal winter and the Indian monsoon region in boreal summer (Newell and Gould-Stewart, 1981).

Especially the Indian summer monsoon has been shown to transport boundary layer air masses into the stratosphere (Randel et al., 2010). Vogel et al. (2015) investigated the source regions and the dynamics of the Asian monsoon anticyclone, which strongly influences the transport in the Asian upper troposphere and lower stratosphere (UTLS) during boreal summer. While Orbe et al. (2015) researched the influence of Asian boundary layer air in the anticyclone, Tissier and Legras (2016) detected convective sources of air masses crossing the tropopause in this region. Recently, measurements of atmospheric trace gases in the anticyclone showed both stratospheric and boundary layer influences within the Asian monsoon anticyclone (Gottschaldt et al., 2017). The emissions of VSLSs from the Pacific Ocean, their atmospheric mixing ratios, and transport to the stratosphere have been measured and modeled in various studies (Tegtmeier et al., 2012, 2013; Hossaini et al., 2016; and observations listed therein), but the uncertainty of Indian Ocean emissions and their contribution to stratospheric bromine is still large (Liang et al., 2014). The Indian Ocean emissions could be quite high based on two oceanic measurement campaigns in the marginal seas (Yamamoto et al., 2001; Roy et al., 2011), as well as extrapolations from other oceans (Ziska et al., 2013) and top-down source estimates (Liang et al., 2010). They have the potential to significantly contribute to stratospheric bromine (Liang et al., 2014; Hossaini et al., 2016). Based on the first measurements of enhanced surface seawater concentrations of bromoform and dibromomethane from the subtropical and tropical west Indian Ocean in 2014, Fiehn et al. (2017) calculated strong emissions and diagnosed stratospheric injection of these two VSLS in the southeastern part of the Asian monsoon anticyclone in July and August 2014 with Lagrangian model calculations. VSLS tracers with different lifetimes revealed a strong seasonality in the transport strength from the tropical west Indian Ocean to the stratosphere, with maximum transport in boreal spring, when the main uplift occurs over this ocean basin (Fiehn et al., 2018).

The atmospheric distribution and the delivery of bromoform to the stratosphere have been the topic of many global chemistry transport and chemistry climate modeling studies. These studies used different approaches to constrain the input of VSLSs from the ocean to the atmosphere: fixed uniform VSLS mixing ratios in the boundary layer (Hossaini et al., 2010, 2012; Morgenstern et al., 2017) or in the upper troposphere (Aschmann et al., 2009, 2011; Aschmann and Sinnhuber, 2013); prescribed emissions as homogeneous fields (Dvortsov et al., 1999; Nielsen and Douglass, 2001) or according to one of the emission inventories described above (Warwick et al., 2006; Hossaini et al., 2013, 2016; Liang et al., 2014; Tegtmeier et al., 2015; or prescribed water concentrations to calculate emissions online (Lennartz et al., 2015). 
From this large set, only a few studies have considered seasonally varying surface water concentrations or emissions in the models (Lennartz et al., 2015; Tegtmeier et al., 2015; Hossaini et al., 2016).

The seasonality of atmospheric mixing ratios is influenced by varying emissions as well as chemical degradation and transport processes. Liang et al. (2010) could reproduce the seasonality of atmospheric bromoform mixing ratios in the lower troposphere from available aircraft observations using annually averaged emissions, concluding that the seasonality was mainly determined by chemical loss in the atmosphere and tropospheric transport. On the other hand, Lennartz et al. (2015) were not able to match the observed seasonality in atmospheric bromoform mixing ratios at ground-based stations, concluding that a seasonality in the bromoform sources was missing. The Stemmler et al. (2015) emission inventory does not include effects of macroalgae or other coastal sources, other than phytoplankton production. Bromoform production is simulated as a function of phytoplankton growth and is only applicable to the open ocean. Bromoform production in line with primary production shows a much less pronounced seasonal cycle in the tropics as compared to extratropical oceans, such as the Southern Ocean or North Atlantic. The seasonality in the Ziska et al. (2013) emissions is clearly driven by the winds.

Furthermore, available model studies are in disagreement over the main stratospheric injection season and location for bromoform over Asia and the Indian Ocean. Liang et al. (2014) modeled the highest upper tropospheric mixing ratios above the Indian Ocean during boreal winter based on the constant and zonally homogenous emission estimate by Liang et al. (2010). In a multi-model intercomparison study of 11 chemistry transport and chemistry climate models, Hossaini et al. (2016) used three different emission inventories for each model (Liang et al., 2010; Ordóñez et al., 2012; Ziska et al., 2013) of which only one (Ordóñez et al., 2012) was applied with seasonality. Overall, the models mainly agreed on the seasonality of volume mixing ratio (VMR) maxima at the tropical averaged cold point tropopause (CPT), but the absolute values varied within a factor of 3. The locations of the VMR maxima at the CPT above the tropical west Pacific in the December-February season (DJF) were model consistent, but model differences in the strength of the Asian monsoon signature in JJA were high and strongly dependent on the parameterization of convection in the free troposphere and mixing in the boundary layer (Hossaini et al., 2016).

Until now, the influence of seasonally varying emissions on the stratospheric injection of VSLS through the Indian summer monsoon has not been investigated. The combination of spatially and temporally varying marine emissions and high-resolution atmospheric transport will help to answer the question of where and when the main oceanic bromine delivery to the stratosphere occurs above Asia and the Indian Ocean.
In this study, we investigate the influence of seasonally varying bromoform emissions from the tropical Indian and west Pacific Ocean on the stratospheric injection of bromoform and its mixing ratios in the TTL modulated by the Asian monsoon circulation. Our research questions for this study are the following. What is the influence of seasonal bromoform emissions on stratospheric injection through the Indian summer monsoon? Which are the main oceanic source and stratospheric injection regions and seasons for bromoform above the Indian Ocean? What is the difference between using monthly averaged and annually averaged emissions for bromoform injection to the stratosphere?

In Sect. 2, we describe the bromoform emission scenarios that we applied in our transport simulations and the Lagrangian model setup. In Sect. 3, we present and discuss the model results. Uncertainties in our studies are addressed in Sect. 4, and Sect. 5 contains the conclusions.

\section{Data and methods}

\subsection{Emission inventories}

We created two bromoform emission inventories for the tropical Indian Ocean and the west Pacific in 2014 from existing observation (Ziska et al., 2013) and model (Stemmler et al., 2015) inventories scaled with new in situ measurements from the OASIS cruise on RV Sonne in July and August 2014 in the tropical and subtropical Indian Ocean (Fiehn et al., 2017). These inventories were used in the Lagrangian dispersion model to determine the transport of bromoform from the tropical Indian Ocean to the stratosphere in 2014, the year of the OASIS cruise which gives the only existing oceanic data set form the west Indian Ocean.

The emission inventories are based on oceanic concentrations and atmospheric mixing ratios of bromoform as described below (Fig. 1). We calculated emission fields with a monthly resolution for 2014 using the parameterization of air-sea gas exchange by Nightingale et al. (2000), adapted to bromoform according to Quack and Wallace (2003). The air-sea flux is obtained as the product of a transfer coefficient, which mainly depends on wind speed, and the gradient between the VSLS concentration in water and air. We use ERA-Interim $1^{\circ} \times 1^{\circ}$ monthly means in 2014 for the physical parameters wind speed, sea level pressure, and sea surface temperature (SST). The climatological annual mean sea surface salinity field was taken from the World Ocean Atlas 2009. The annual mean of the monthly mean emissions are used for the annually averaged emission scenario. For this study we only consider air-sea fluxes from the tropical Indian Ocean and west Pacific (IO/WP), here defined as the region within $30^{\circ} \mathrm{N}-30^{\circ} \mathrm{S}$ and $30-160^{\circ} \mathrm{E}$. This area is also used for the particle releases in the Lagrangian simulations (Sect. 2.2). 
As a first inventory, the Ziska et al. (2013) climatology was updated with new oceanic and atmospheric measurements from the Halocarbons in the Ocean and Atmosphere (HalOcAt) database. This emission inventory will be called "Ziska Updated" in the following discussion (red lines in Fig. 1). The Ziska et al. (2013) climatology is an observation-based global air-sea flux estimate of bromoform, dibromomethane, and methyl iodide, calculated from the available oceanic and atmospheric surface concentrations within HalOcAt in 2011. The available surface data were classified as coastal, shelf, or open ocean data. The open ocean data were further divided into 21 regions according to the physical and geochemical characteristics of ocean and atmosphere. Measurements were interpolated on a $1^{\circ} \times 1^{\circ}$ grid and extrapolated within the regions using longitude and latitude regressions. The most relevant modification for this study is considering additional observations from the tropical and subtropical west Indian Ocean in July and August 2014 (Fiehn et al., 2017), which are the only measurements of bromocarbons in the tropical open Indian Ocean. In the original Ziska climatology, emission values in the Indian Ocean were based on extrapolations from other ocean basins (Ziska et al., 2013). For this study, the global climatological mean fields of bromoform oceanic concentrations and atmospheric mixing ratios are updated using the ordinary least-squared (OLS) method from Ziska et al. (2013). In the IO/WP area the climatological mean oceanic surface concentrations are $7.8 \mathrm{pmol} \mathrm{m}^{-2} \mathrm{~h}^{-1}$ and the mean atmospheric surface mixing ratio is $1.9 \mathrm{ppt}$ (Fig. 1). The climatological fields were used together with physical data (i.e., wind speed as described above) of higher frequency to calculate monthly mean emissions.

As a second emission inventory, modeled oceanic concentration fields of bromoform (Stemmler et al., 2015) were scaled with in situ observations from the tropical and subtropical Indian Ocean (Fiehn et al., 2017). This emission inventory will be called "Stemmler Scaled" in the following (blue lines in Fig. 1). Stemmler et al. (2015) used a global ocean general circulation model with a biogeochemistry model (MPIOM-HAMOCC; Ilyina et al., 2013) to simulate bromoform cycling in the ocean and to derive emissions to the atmosphere. They used the Ziska et al. (2013) surface atmospheric mixing ratio climatology as boundary conditions for their online air-sea flux calculations. In general, the Stemmler et al. (2015) surface oceanic concentration and air-sea flux climatologies are lower than previously published estimates (see Table 3 in Fiehn et al., 2017 for comparison of tropical bromoform emissions). The low emissions might be partly caused by the use of the temporally constant atmospheric mixing ratios, which are not consistent with the state of the ocean and atmosphere and have been shown to decrease bromoform emissions in a chemistry climate model setup (Lennartz et al., 2015). In this study, we scaled the oceanic bromoform concentrations of the Stemmler et al. (2015) "Dia" experiment. This experiment includes a spatiotemporally variable bromoform production rate, which

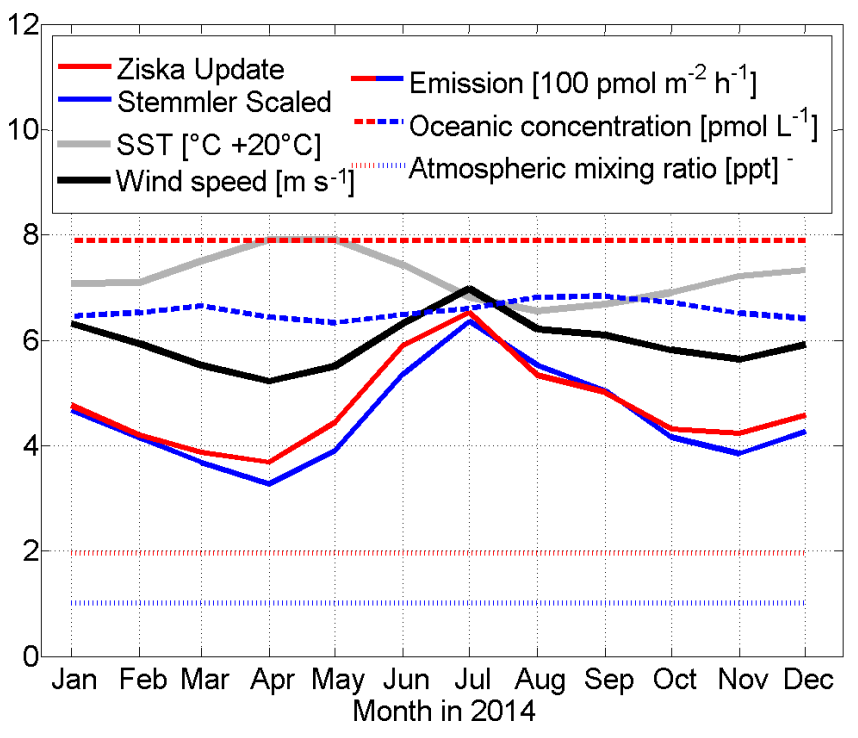

Figure 1. Annual cycle of monthly mean emissions, surface water concentrations, and atmospheric mixing ratios of bromoform, as well as monthly mean surface wind speed and SST in the IO/WP release area in 2014 for the two inventories.

leads to the most realistic bromoform emission distribution. The scaling of concentrations was done based on oceanic measurements from the OASIS cruise in the Indian Ocean (Fiehn et al., 2017) and the TransBrom transit across the west Pacific Ocean (Krüger and Quack, 2013). For every measured bromoform concentration in the ocean surface during these two campaigns, the model concentration in the corresponding grid box during the respective months of the climatology was selected and a linear scaling factor was calculated to obtain the measured value. The average scaling factor of 3.48 was then homogeneously applied to the modeled sea surface bromoform concentrations in the IO/WP release area of Stemmler et al. (2015). For our "Stemmler Scaled" emission inventory, we use monthly mean surface oceanic concentrations, which were on average between 6.3 and $6.8 \mathrm{pmol} \mathrm{m}^{-2} \mathrm{~h}^{-1}$ in the IO/WP, and a constant atmospheric bromoform mixing ratio of $1 \mathrm{ppt}$, which corresponds to the observed average atmospheric mixing ratio of bromoform from the OASIS (Fiehn et al., 2017) and TransBrom ship campaigns (Ziska et al., 2013), to calculate the monthly varying emission fields (Fig. 1).

\subsection{FLEXPART calculations}

For our transport calculations, we use the Lagrangian particle dispersion model FLEXPART of the Norwegian Institute for Air Research in the Atmosphere and Climate Department (Stohl et al., 2005), which has been evaluated in previous studies (Stohl et al., 1998; Stohl and Trickl, 1999). The model includes moist convection and turbulence parameterizations in the atmospheric boundary layer and free tro- 
posphere (Stohl and Thomson, 1999; Forster et al., 2007). In this study, we employ version 9.2 of FLEXPART, which has been modified to incorporate atmospheric lifetime profiles for the decay of transported VSLSs. We use the ECMWF reanalysis product ERA-Interim (Dee et al., 2011) with a horizontal resolution of $1^{\circ} \times 1^{\circ}$ and 60 vertical model levels as meteorological input fields, providing air temperature, winds, boundary layer height, and specific humidity, as well as convective and large-scale precipitation with a 3-hourly temporal resolution. The vertical winds in hybrid coordinates were mass-consistently calculated from spectral data by the preprocessor (Stohl et al., 2005). We record the transport model output every $12 \mathrm{~h}$.

We ran the FLEXPART model using the monthly resolved and annually averaged emission fields for each of the Ziska Updated and Stemmler Scaled scenarios described above. According to these emission scenarios, we calculated the mass of bromoform released from each $1^{\circ} \times 1^{\circ}$ grid cell during 1 day. We released one particle per day and grid cell from the IO/WP release area $\left(30^{\circ} \mathrm{N}-30^{\circ} \mathrm{S}, 30-160^{\circ} \mathrm{E}\right)$ with the released mass attached. An exponential mass decay is realized through the application of the lifetime profile of bromoform from Hossaini et al. (2010). For stratospheric injection we consider particles that reach above the CPT. We only calculate bromoform source gas injection to the stratosphere, and do not consider product gases. The CPT is calculated online based on the ERA-Interim data. The seasonal mean CPT height is displayed in Fig. S1 in the Supplement. We define the stratospheric transport efficiency as the mass of bromoform entrained to the stratosphere divided by the emitted mass. FLEXPART output of trajectory positions and VMR fields are recorded 12-hourly and then averaged over 1 month.

\section{Results}

\subsection{Bromoform emissions from the Indian Ocean and west Pacific}

The 2014 annual mean bromoform air-sea flux maps for the Ziska Updated and the Stemmler Scaled emission inventories in the IO/WP release area are shown in the top row of Fig. 2. These emission distributions are used in the annually averaged emission scenario in FLEXPART. The Ziska Updated bromoform emission inventory includes high emissions along the Northern Hemisphere coastlines, mostly caused by macroalgae (1500-3000 $\mathrm{pmol} \mathrm{m}^{-2} \mathrm{~h}^{-1}$ ), and in the central Bay of Bengal (up to $5000 \mathrm{pmol} \mathrm{m}^{-2} \mathrm{~h}^{-1}$ ). An area of high emissions is the southern tropical Indian Ocean $\left(1000 \mathrm{pmol} \mathrm{m}^{-2} \mathrm{~h}^{-1}\right)$, while the flux from the tropical northwestern Pacific is negative, meaning that the ocean takes up bromoform from the atmosphere. This is caused by low oceanic concentrations; elevated atmospheric mixing ratios, likely from coastal regions off Japan and
China; and low water temperatures, which enable the ocean to take up more gas from the atmosphere. The Stemmler Scaled bromoform emission inventory shows emission hot spots at the Horn of Africa (2000 $\left.\mathrm{pmol} \mathrm{m}^{-2} \mathrm{~h}^{-1}\right)$, south of the Oman coast $\left(1700 \mathrm{pmol} \mathrm{m}^{-2} \mathrm{~h}^{-1}\right)$, and in the Torres Strait north of the Cape York Peninsula of Australia (up to $5000 \mathrm{pmol} \mathrm{m}^{-2} \mathrm{~h}^{-1}$ ). The two inventories are similar in their main emission regions, the Arabian Sea and the Bay of Bengal, but show two significant differences: (1) near the coast the Ziska Updated emissions are much higher than the Stemmler Scaled emissions, because the bromoform module implemented in HAMOCC (Hamburg Model of the Ocean Carbon Cycle; Stemmler et al., 2015) does not account for bromoform production by macroalgae and anthropogenic influences near the coastline. Furthermore, HAMOCC is a global carbon cycle model and is not designed to represent coastal plankton growth or distributions; processes relevant on shelves - such as riverine discharge of nutrients, tides, or sediment resuspension - are not considered. (2) The air-sea fluxes in the west Pacific Ocean include negative fluxes north of $20^{\circ} \mathrm{N}$ in the Ziska Updated inventory, while they are small but positive in the Stemmler Scaled inventory.

The seasonal mean emission fields show the intra-annual variability in bromoform emissions (Fig. 2). Emissions in the IO/WP area are high in boreal winter (December-February, DJF) and summer (June-August, JJA) and lower in boreal spring (March-May, MAM) and fall (September-November, SON) for both inventories (see also Fig. 1). High emissions of the Ziska Updated inventory are concentrated along the northern Indian Ocean coastline, the central Bay of Bengal, and the tropical southern Indian Ocean, with seasonal variations mainly driven by wind speed. Hot spots in the Stemmler Scaled emissions mainly result from the high phytoplankton productivity in the biogeochemical model (Stemmler et al., 2015).

We compare the annual mean emissions of the two created emission inventories with their progenitors and two topdown inventories (Table 1). In Ziska Updated, the emission distribution has changed compared to Ziska et al. (2013), while the Stemmler Scaled bromoform emission inventory mainly differs from Stemmler et al. (2015) in the total amount of bromoform emitted. The Ziska Updated inventory incorporates new high concentrations measured in the west Indian Ocean compared to Ziska et al. (2013), increasing the emissions in the southern Indian Ocean. Overall, the Ziska annual mean bromoform emission from the

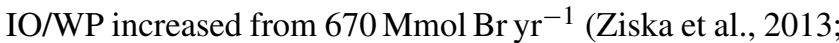
OLS) to $750 \mathrm{Mmol} \mathrm{Br} \mathrm{yr}^{-1}$ (Ziska Updated, this study). The Stemmler Scaled emissions from the IO/WP release area are $760 \mathrm{Mmol} \mathrm{Br} \mathrm{yr}^{-1}$, while Stemmler et al. (2015) modeled

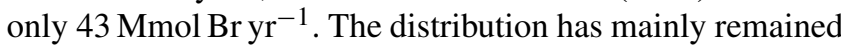
the same for this inventory. The large difference in the emission strength results from scaling the surface water concentrations, the applied homogenous atmospheric mixing ratios of 1 ppt instead of the Ziska et al. (2013) climatology and 
Table 1. Tropical coastal and open Indian Ocean (IO: 40-90 E) annual mean emissions for different bromoform emission inventories. Values are given as fixed number, approximation, or range (representing spatial variation) depending on the design of the inventory.

\begin{tabular}{lrr}
\hline Inventory & $\begin{array}{r}\text { Coastal IO emissions } \\
\left(\mathrm{pmol} \mathrm{m}^{-2} \mathrm{~h}^{-1}\right)\end{array}$ & $\begin{array}{r}\text { Open IO emissions } \\
\left(\mathrm{pmol} \mathrm{m}^{-2} \mathrm{~h}^{-1}\right)\end{array}$ \\
\hline Liang et al. (2010) & 1500 & $150-1100$ \\
Ordóñez et al. (2012) & $\sim 950$ & $\sim 350$ \\
Stemmler et al. (2015) & $0-300$ & $0-130$ \\
Ziska et al. (2013) & $500-3000$ & $-300-800$ \\
Ziska Updated, annual (this study) & $300-2500$ & $-300-800$ \\
Stemmler Scaled, annual (this study) & $300-2300$ & $200-800$ \\
\hline
\end{tabular}

the ERA-Interim meteorological fields instead of the NCEP (National Centers for Environmental Prediction) data used in Stemmler et al. (2015). The Ziska Updated and Stemmler Scaled inventories show similarities in the IO/WP region with previously published top-down bromoform emission inventories of Liang et al. (2010) and Ordóñez et al. (2012). Comparing spatial patterns, all six inventories in Table 1 include high emissions in the tropics, while only Liang et al. (2010) assume zonally homogenous emissions. An estimate of the emission strength for coastal and open ocean regions of the Indian Ocean for the annual mean of six emission inventories is given in Table 1. The coastal emissions are similar in magnitude for all inventories, except Stemmler et al. (2015), which is much lower, due to the lack of coastal macroalgal production and other potential processes relevant in the coastal ocean. The high emissions along the coasts of Somalia and Oman in the Stemmler Scaled inventory are caused by high wind speeds during boreal summer and coastal upwelling, entailing bromoform production (Fig. 2). This phenomenon is not captured in the Ziska Updated inventory due to missing bromoform measurements in this biogeochemical regime, but it is partly balanced by higher coastal emissions, like in the Liang and Ordoñez inventories.

The annual cycles of emission for Ziska Updated and Stemmler Scaled are very similar with a maximum in July and a secondary maximum in January and minima in April and November (Fig. 1). While the Ziska Updated inventory uses annually averaged oceanic concentrations, the Stemmler Scaled inventory includes monthly resolved concentrations calculated from temporally variable source-sink dynamics, such as production by plankton, degradation, emissions, and transport by mixing and ocean currents (Stemmler et al., 2015). Both scenarios show the highest emissions in boreal summer, which has the highest wind speed, a quadratic factor in the air-sea gas exchange parameterization we used (Nightingale et al., 2000). We calculated the correlation between the annual cycles of emission from the IO/WP release area with each of the other variables (Table 2). Strongest correlations of the emission cycle exist with the wind speed and the SST. The correlation between emissions and oceanic con-
Table 2. Correlation between the annual cycle of bromoform emission and bromoform surface water concentration, wind speed, and SST from Fig. 1 using Spearman rank correlation. Bold face correlations are significant at the $95 \%$ level according to a permutation test. Variables without an annual cycle (i.e., Ziska Updated surface water concentration and both atmospheric mixing ratios) could not be correlated.

\begin{tabular}{lrr}
\hline Variable & \multicolumn{2}{c}{ Bromoform emission } \\
\cline { 2 - 3 } & $\begin{array}{r}\text { Stemmler } \\
\text { Scaled }\end{array}$ & $\begin{array}{r}\text { Ziska } \\
\text { Updated }\end{array}$ \\
\hline Surface water concentration & 0.36 & - \\
Wind speed & $\mathbf{0 . 9 2}$ & $\mathbf{0 . 8 6}$ \\
SST & $\mathbf{- 0 . 7 1}$ & -0.55 \\
\hline
\end{tabular}

centrations for Stemmler Scaled are weak. Thus, from this table we can infer that the annual cycle of emissions in the Indian Ocean is mainly driven by the wind speed, which varies strongly over the year, changing between the weak northeast (winter) and strong southwest (summer) monsoon winds.

\subsection{Comparison with observations}

To evaluate our flux and transport calculations, we compare the modeled VMR with observations from selected ship and aircraft campaigns. A comparison of modeled and observed VMRs may also determine where sources in the different emission inventories might be missing or have been overestimated. We compare the modeled VMR at $100 \mathrm{~m}$ height with the ship cruise observations (Table 3, Figs. S2 and S3) from OASIS in the west Indian Ocean (Fiehn et al., 2017), TransBrom across the west Pacific (Ziska et al., 2013), and SHIVA in the South China and Sulu seas (Fuhlbrügge et al., 2016). Note that we compare with the modeled VMR of the respective month of the cruise but always for the year 2014, and thus expect higher deviations for TransBrom (2009) and SHIVA (2011) than for OASIS (2014).

In the marine atmospheric boundary layer (MABL), which extends from the surface to about $1 \mathrm{~km}$, high VMRs mainly reflect emission hot spots. For both emission inventories, the modeled VMRs at $100 \mathrm{~m}$ height are highest above the In- 


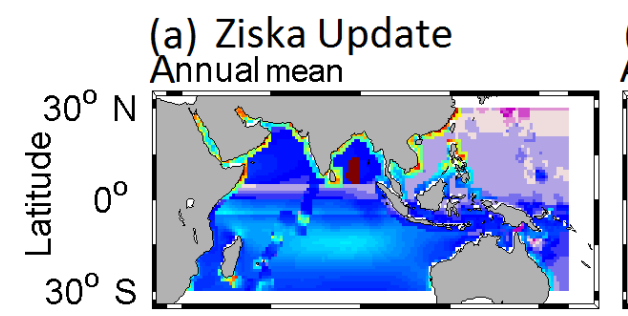

(b) Stemmler Scaled Annual mean
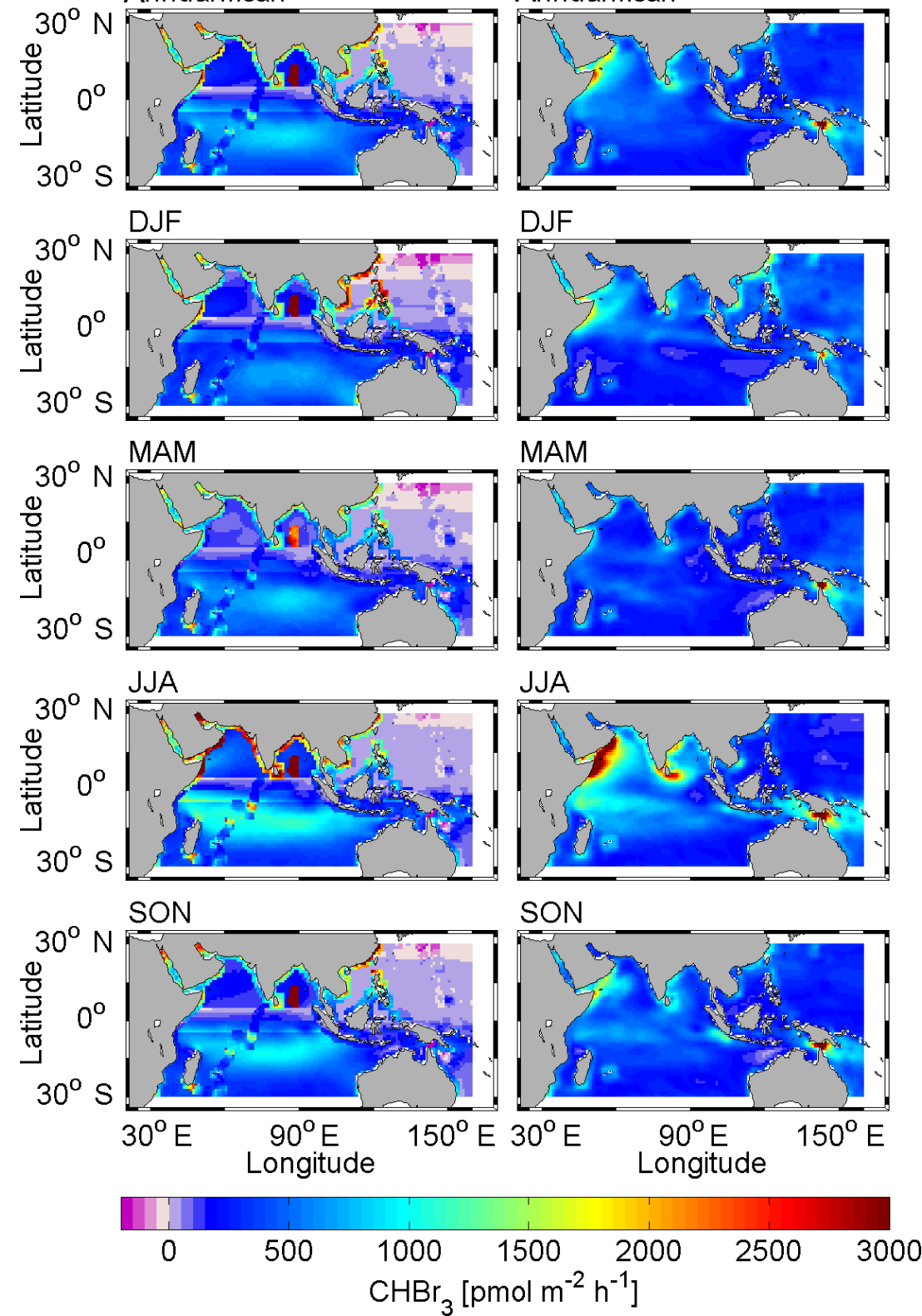

Figure 2. Annual and seasonal mean bromoform emissions from the Indian Ocean and west Pacific release area $\left(30^{\circ} \mathrm{N}-30^{\circ} \mathrm{S}, 30-160^{\circ} \mathrm{E}\right)$ of the inventories Ziska Updated (a) and Stemmler Scaled (b).

dian Ocean and Asian coasts (Fig. S2). Besides their different coastal or open-ocean distribution of emissions, they display similar hot spots in JJA and SON in the Arabian Sea and the Bay of Bengal, caused by high emissions in these basins during the summer monsoon season with high surface wind speeds. For most cruise observations, the modeled VMRs are lower than the measurements (Table 3, Fig. S3), which might be partly due to the experimental setup of including only emissions from the IO/WP. It is likely that oceanic sources from the tropical central Pacific also contribute to the VMRs above the IO/WP (see Fig. 7 in Liang et al., 2014) and our modeled VMR are generally too low because we do not use global emissions. Our comparison hints at missing coastal emissions in the two inventories and an overall uncertainty in the tropical west Pacific emissions (Supplement text, Fig. S3).

In the free troposphere, we compare the modeled VMRs with available observations from the CARIBIC aircraft observatory flights between November 2012 and February 2013 at around $11 \mathrm{~km}$ height above Southeast Asia (Wisher et al., 
Table 3. Mean bromoform volume mixing ratios (VMRs, in ppt) observed during the research cruises and modeled with FLEXPART at $100 \mathrm{~m}$ height for the same location and month as the observation, but for the year 2014 .

\begin{tabular}{lllccc}
\hline VMR (ppt) & & & $\begin{array}{c}\text { west Pacific, } \\
\text { TransBrom }\end{array}$ & $\begin{array}{c}\text { Indian Ocean, } \\
\text { OASIS }\end{array}$ & $\begin{array}{c}\text { South China Sea, } \\
\text { SHIVA }\end{array}$ \\
\cline { 4 - 6 } & Emission inventory & Emission scenario & Oct & Jul & Nov \\
\hline Observation & Ziska Updated & in situ & $0.92^{1}$ & $1.28^{2}$ & $2.02^{3}$ \\
\hline \multirow{3}{*}{ Modeled for 2014 } & annually averaged & 0.12 & 0.72 & 0.52 \\
& & monthly averaged & 0.10 & 1.01 & 0.41 \\
\cline { 3 - 6 } & \multirow{2}{*}{ Stemmler Scaled } & annually averaged & 0.35 & 0.44 & 0.44 \\
& & monthly averaged & 0.30 & 0.63 & 0.35 \\
\hline
\end{tabular}

${ }^{1}$ TransBrom 2009 (Ziska et al., 2013). ${ }^{2}$ OASIS 2014 (Fiehn et al., 2017). ${ }^{3}$ SHIVA 2011 (Fuhlbrügge et al., 2016).

2014). The range and latitudinal gradient of FLEXPART VMRs compare well with the aircraft measurements made between 15 and $30^{\circ} \mathrm{N}$ (Fig. S4). Still, at the Equator and in the north our simulations deliver less bromoform into the South Asian region than observed during CARIBIC. We account for this as missing oceanic emissions from outside the release area in the central and east Pacific west of $160^{\circ} \mathrm{E}$ and to a likely underestimation of coastal sources in the two inventories. The assumption is supported by the fact that mixing ratios south of $10^{\circ} \mathrm{N}$ modeled with Ziska Updated are lower than those modeled with Stemmler Scaled (not shown), caused by lower emissions from the west Pacific in Ziska Updated.

The modeled annual mean mixing ratio profiles of bromoform up to $20 \mathrm{~km}$ height are largest over the Indian Ocean and lowest over the west Pacific (Fig. 3a). Although mixing ratios are highest above the Indian Ocean, the above comparison with CARIBIC showed that here contributions from the central Pacific may also be important.

\subsection{Ocean-to-stratosphere transport of bromoform}

In this section we analyze the main oceanic source regions and stratospheric injection regions for bromoform from the Indian Ocean and the west Pacific. Here, we focus on emission scenarios with monthly variations. A comparison of stratospheric injection results using annually averaged emissions follows in the next section.

\subsubsection{Oceanic source regions}

Figure $4 \mathrm{a}$ and $\mathrm{b}$ show the distribution of bromoform mass delivered to the stratosphere displayed at the oceanic release locations, which depicts the oceanic source regions according to the two emission inventories. For both emission inventories (Fig. 4a and b) the most important source regions for bromoform to the stratosphere are the Asian coast, the Arabian Sea, and the Bay of Bengal, especially in JJA. During this season, the emissions from these regions are high (Fig. 1) providing bromoform to the Indian summer monsoon con- (a) Tropics

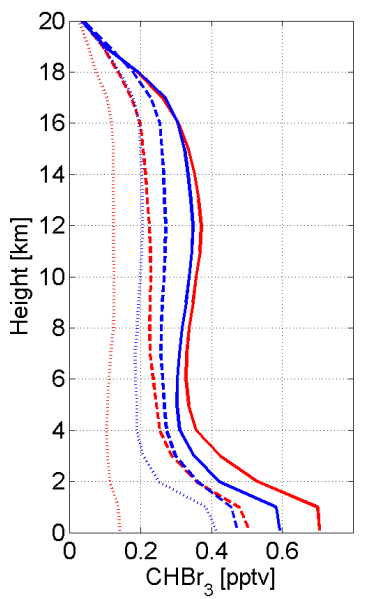

Ziska IO Stemmler IO

----Ziska SCS ----. Stemmler SCS

..... Ziska WP .......... Stemmler WP (b) AMA, JJA

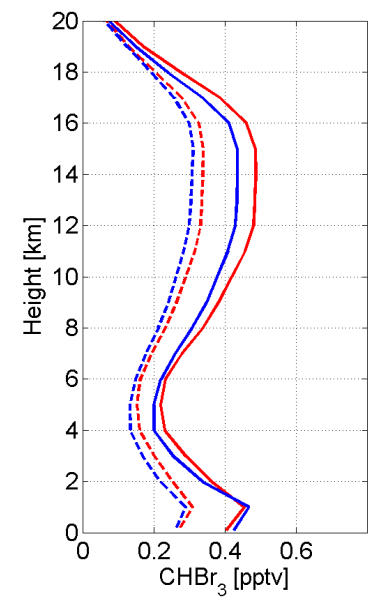

Figure 3. (a) Annual mean tropical $\left(20^{\circ} \mathrm{S}-20^{\circ} \mathrm{N}\right)$ VMR profiles of bromoform over the Indian Ocean (IO: $40-90^{\circ} \mathrm{E}$ ), the South China Sea (SCS: $90-130^{\circ}$ E), and the west Pacific (WP: $130-160^{\circ}$ E) from the Ziska Updated and Stemmler Scaled inventories with monthly averaged emissions. (b) Bromoform VMR profiles in the Asian monsoon anticyclone region (AMA: $10-40^{\circ} \mathrm{N}, 20-90^{\circ} \mathrm{E}$ ) in JJA from both inventories with monthly and annually averaged emissions.

vection over India and the Bay of Bengal. For the Ziska Updated inventory (Fig. 4a), the southern tropical Indian Ocean is also an important source region, while the open west $\mathrm{Pa}-$ cific delivers hardly any bromoform to the stratosphere during all seasons due to low and partly negative emissions. Using the Stemmler Scaled inventory (Fig. 4b), the equatorial west Pacific Ocean provides a secondary bromoform source to the stratosphere, which is strongest in DJF. 


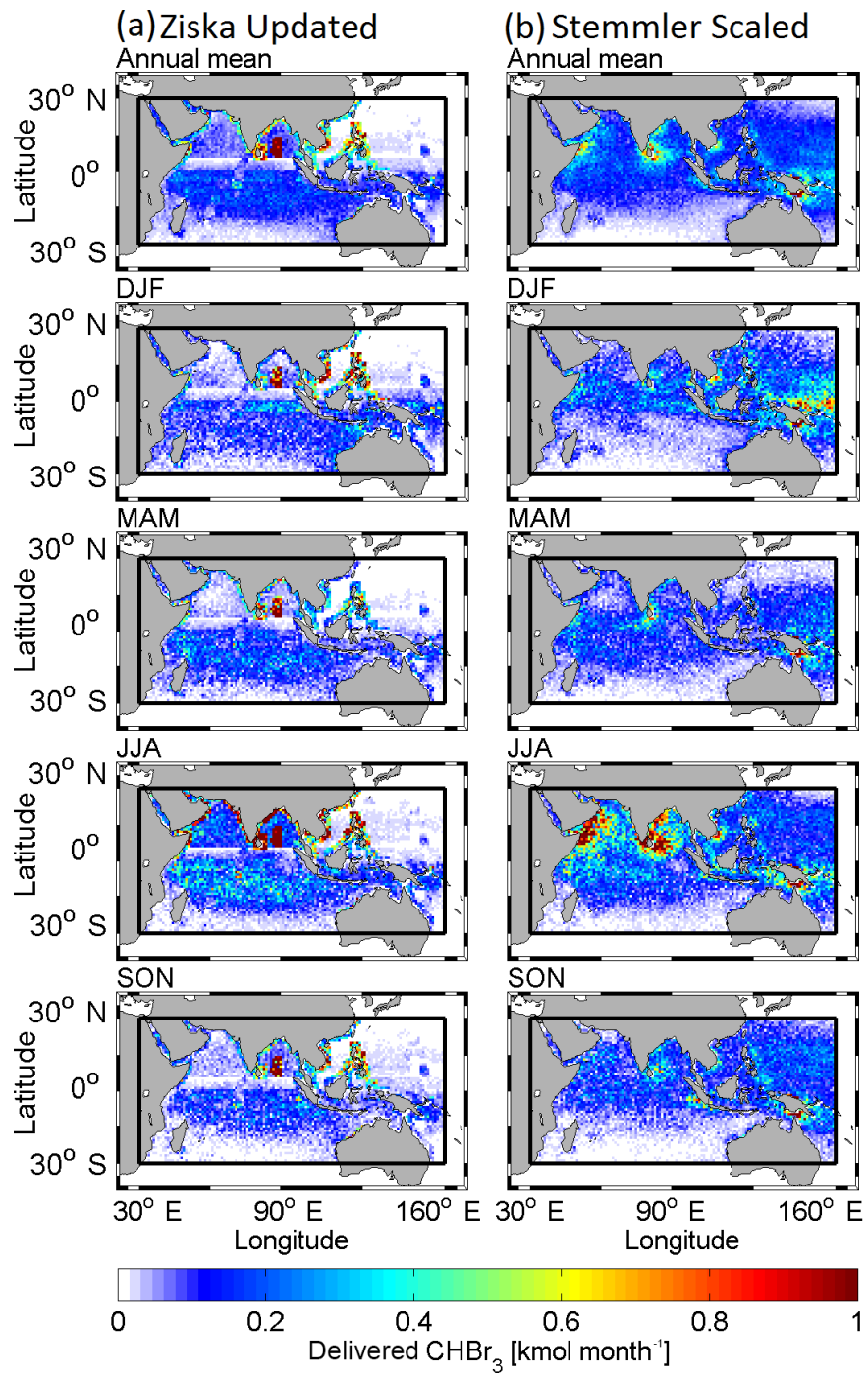

(c)Transport efficiency
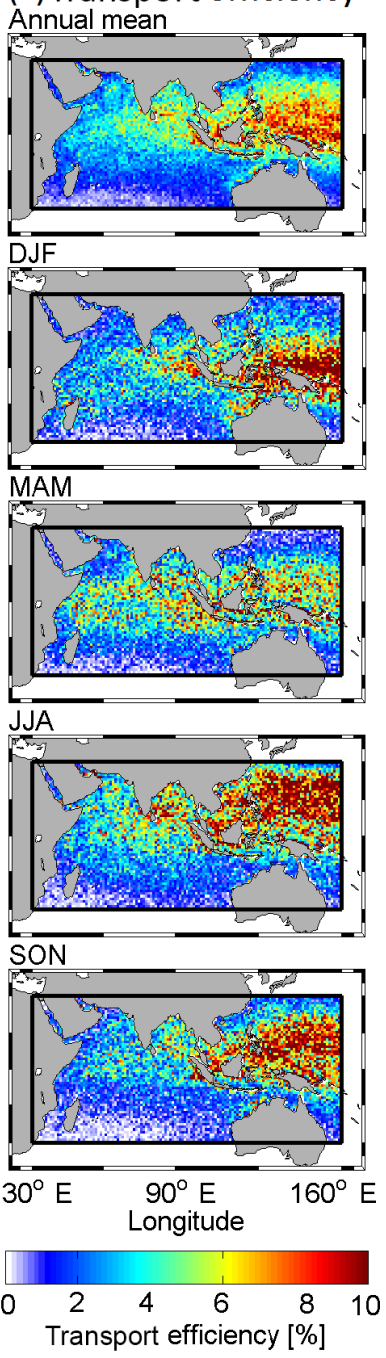

Figure 4. (a) Oceanic source regions of bromoform delivered to the cold point tropopause (CPT) for the Ziska Updated inventory with monthly averaged emissions. (b) Like (a) but for Stemmler Scaled. (c) Source region transport efficiency for bromoform delivery to the CPT from (a) and (b). The black box depicts the Indian Ocean and west Pacific release area.

Figure $4 \mathrm{c}$ depicts the distribution of the transport efficiency of bromoform to the stratosphere, which results from dividing the mass delivered to the stratosphere (Fig. 4a) by the mass emitted from the ocean (from Fig. 2) and allocating this to the location of emission. The spatial distribution of transport efficiency is very similar for both emission inventories and this is why we only show the distribution for Ziska Updated. The transport efficiency maps (Fig. 4c) show that the tropical west Pacific is the most efficient region at transporting bromoform from the ocean to the stratosphere in the annual mean. The maximum efficiency shifts from the west Pacific Equator in DJF toward the north in JJA and SON. In MAM the transport efficiency is more evenly distributed between the tropical Indian Ocean and the west Pacific. In JJA the Bay of Bengal also displays elevated transport efficiencies.

When comparing emissions (Fig. 2), delivered mass (Fig. 4a and b), and transport efficiency (Fig. 4c), we can identify the oceanic regions where the stratospheric delivery is determined by the emissions and those where the transport dominates stratospheric injection. If source regions with high transport efficiency coincide with high oceanic emissions, the stratospheric injection from this region is mainly emission-driven; if source regions with high transport efficiency coincide with low emissions, then the stratospheric delivery is transport-driven. Analyzing the annual mean, the Arabian Sea and the Bay of Bengal are emission-driven source regions for the stratosphere: these ocean basins show low transport efficiencies $(2 \%-5 \%)$, but due to the high 
emissions they deliver maximum bromoform to the stratosphere. The west Pacific is a transport-driven source region: it contributes to stratospheric delivery through the generally high transport efficiency (6\%-9\%) despite low emissions in this region in both the Ziska Updated and the Stemmler Scaled inventories. This also means that small changes in the VSLS emissions in the west Pacific will have a strong influence on the total mass delivered to the stratosphere, which makes it important to better constrain present and future emissions from this key region.

Tegtmeier et al. (2015) also identified important bromoform source regions in the tropical oceans. They used a combination of bromoform emissions from Ziska et al. (2013) and ozone depletion potential (ODP) calculations (Pisso et al., 2010) to infer the importance of different oceanic regions for stratospheric ozone depletion, including an emission seasonality. The tropical west Pacific significantly contributed to ODP-weighted emissions all year round. In accordance with our results, the main contribution in boreal summer comes from the tropical Asian coastlines and the Indian Ocean.

\subsubsection{Stratospheric injection regions}

The modeled geographical location at the CPT where bromoform passes through to the stratosphere, here called stratospheric injection regions, for Ziska Updated and Stemmler Scaled inventories with monthly averaged emissions are depicted in Fig. 5. In the annual mean, the injection maximum for both inventories occurs over the southern tip of India (Fig. 5a, b, top row). This maximum mainly results from the strong emissions in JJA and the fast uplift with the Asian summer monsoon circulation. The Stemmler Scaled inventory also shows a secondary injection maximum over the equatorial west Pacific, which the Ziska Updated lacks. It is present in all seasons, but most pronounced in DJF. The weaker stratospheric injection above the west Pacific from Ziska Updated is the most obvious pattern throughout all seasons and in the annual mean of the difference between the two inventories (Fig. 5c). The Ziska Updated inventory, on the other hand, displays stronger injection above the Bay of Bengal, caused by the strong coastal and central Bay of Bengal emissions in this inventory.

\subsection{Monthly vs. annually averaged bromoform emissions}

For this study, we calculated the ocean to stratosphere transport of bromoform using monthly averaged and annually averaged emission fields for 2014. This enables us to detect the differences between the two experimental setups and to find out which season and region delivers most bromoform to the stratosphere above the Indian Ocean.

Figure 6 shows the annual cycle of bromoform emissions, transport efficiency, and source gas injection comparing the monthly and annually averaged emission scenarios of Ziska
Table 4. Total annual stratospheric injection of bromoform emitted from the IO/WP region.

\begin{tabular}{lcc}
\hline & $\begin{array}{c}\text { Stemmler Scaled } \\
\left(\mathrm{Mmol} \mathrm{Br} \mathrm{yr}^{-1}\right)\end{array}$ & $\begin{array}{c}\text { Ziska Updated } \\
\left(\mathrm{Mmol} \mathrm{Br} \mathrm{yr}^{-1}\right)\end{array}$ \\
\hline $\begin{array}{l}\text { Annually averaged } \\
\text { emissions }\end{array}$ & 28.7 & 24.2 \\
$\begin{array}{l}\text { Monthly averaged } \\
\text { emissions }\end{array}$ & 28.2 & 24.5 \\
\hline
\end{tabular}

Updated and Stemmler Scaled simulations plotted at the time of particle release from the ocean. The annual cycles of monthly averaged emissions display maxima in January and July and minimum emissions in April and November (Fig. 6a, see also Fig. 1). Monthly-averaged emissions are higher than the annual mean from June to September. The annual cycle of bromoform transport efficiency, which is the injection to the stratosphere divided by the total IO/WP emissions, displays two maxima, one in July and one in January (Fig. 6b). Generally, the transport efficiency is higher for the Stemmler Scaled than for the Ziska Updated emissions, because Stemmler Scaled has higher emissions in the west Pacific, which is the most efficient source region for the stratosphere (Fig. 4c). The combination of the emission cycles and transport efficiency results in the annual cycles of stratospheric injection of bromoform from the IO/WP area (Fig. 6c). Using annually averaged emissions, the annual cycle of stratospheric injection has the same seasonality as the transport efficiency and a maximum from May to July. Using monthly averaged emissions, the annual cycle of injection is amplified due to the similar seasonality in emissions and transport efficiency. The very high emissions in JJA combined with highest transport efficiencies result in the highest stratospheric injection during this season using monthly averaged emissions. There is, thus, a temporal shift in the maximum injection months from MJJ using the annually averaged emission scenario to JJA applying the monthly resolution.

The total annual injection of bromoform to the stratosphere is similar for monthly or annually averaged emissions (Table 4), which shows that the emission seasonality (Fig. 6c) does not influence the total annual mass entrained to the stratosphere in our experimental setup for the year 2014. Nonetheless, the differing annual cycles of bromoform injection to the stratosphere for monthly and annually averaged emissions (Fig. 6c) also influence the regional pattern of injection to the stratosphere.

We distinguish spatial differences in the stratospheric injection of bromoform between the monthly and annually averaged emission scenarios of the Ziska Updated inventory by examining the atmospheric VMRs at $17 \mathrm{~km}$ altitude (Fig. 7). This height is a good approximation for the tropical CPT height observed above the tropical Indian Ocean and west Pacific (Fiehn et al., 2017, not shown here), and it can be 


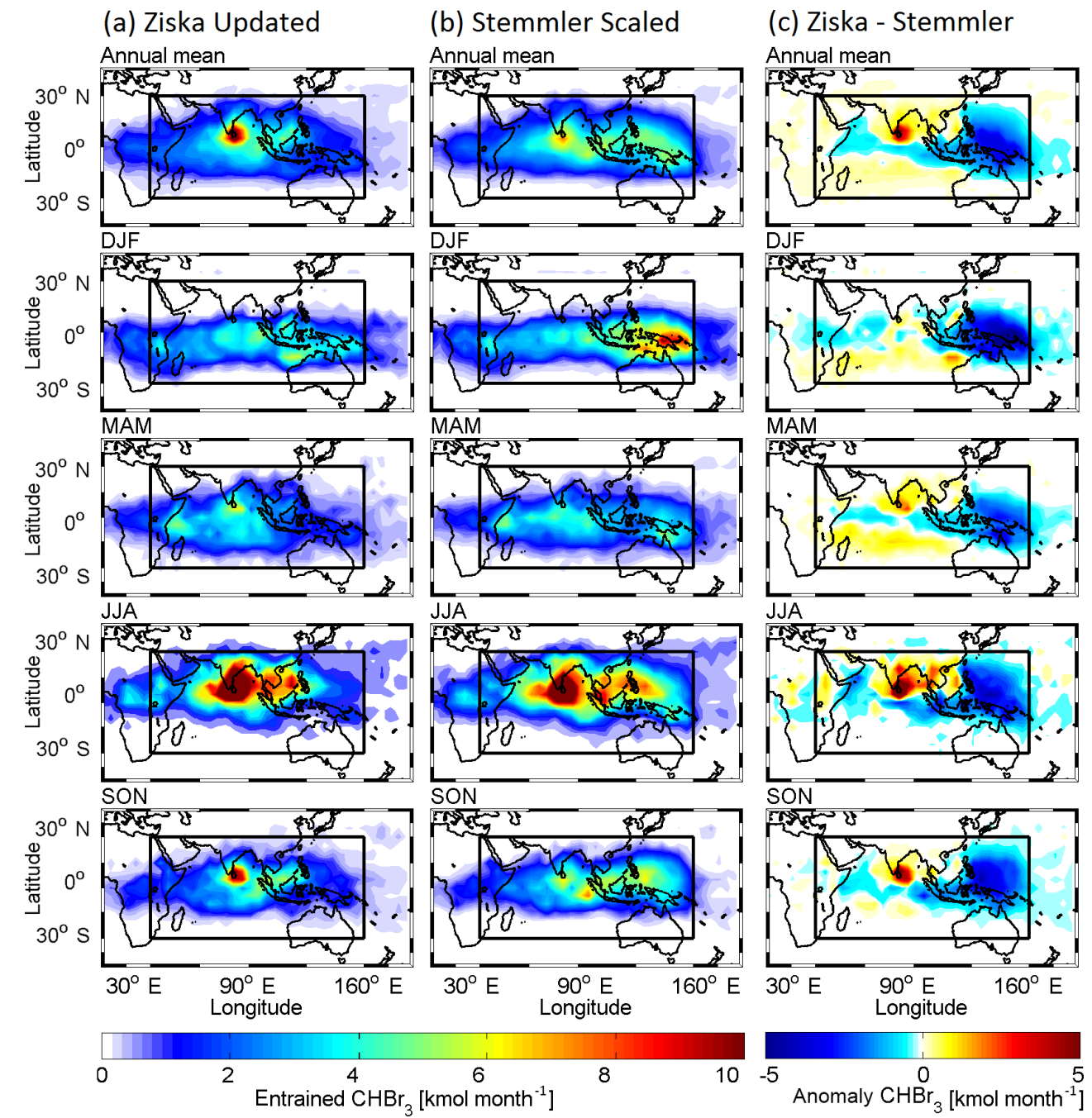

Figure 5. Amount of $\mathrm{CHBr}_{3}$ injected to the stratosphere within $1^{\circ} \times 1^{\circ}$ grid cells plotted on the geographical location of CPT crossing for monthly averaged bromoform emissions for (a) Ziska Updated and (b) Stemmler Scaled emission inventories. (c) Differences in injection between the two inventories (a) minus (b). The black box depicts the Indian Ocean and west Pacific release area.

up to $18 \mathrm{~km}$ high in the Asian monsoon anticyclone in boreal summer (Munchak and Pan, 2014). High VMRs generally represent regions with enhanced uplift of bromoform from the ocean, but additionally indicate an accumulation in a certain region as, for example, the Asian summer monsoon anticyclone. Using annually averaged emissions (Fig. 7a), the maximum VMR region covers the tropical southwestern and central-northern Indian Ocean in the annual mean. This maximum is strongest for this scenario in MAM. For the monthly averaged emission scenario (Fig. 7b), the annual mean region of highest VMR at $17 \mathrm{~km}$ is also located above the tropical southwestern and central-northern Indian Ocean, but the season with highest VMR is JJA. We, thus, diagnose different maximum bromoform VMR seasons using monthly vs. annually averaged emissions. The differences between VMR at $17 \mathrm{~km}$ for the two scenarios are displayed in Fig. 7c. In the annual mean, the VMR is lower north of $15^{\circ} \mathrm{N}$ and higher south of $15^{\circ} \mathrm{N}$ using annually averaged emissions than with monthly averaged emissions. In MAM, the annually averaged emissions deliver much more bromoform to $17 \mathrm{~km}$ height than monthly averaged emissions. This is reversed in JJA and SON, when monthly averaged emissions lead to higher VMR in the Asian monsoon anticyclone region in JJA and across the whole Indian Ocean and Asian area in SON. This difference in the VMR in the Asian monsoon anticyclone between the scenarios is also visible in the bromoform VMR profiles in Fig. 3b, revealing up to $50 \%$ more injection of bromoform into the UTLS region.

The respective figure for the Stemmler Scaled emission inventory displays very similar patterns (Fig. S5). The difference in the injection regions of bromoform mass at the CPT between the two scenarios also shows a similar seasonality in the anomalies between monthly and annually averaged emissions (Fig. S6), except for SON when the annually 

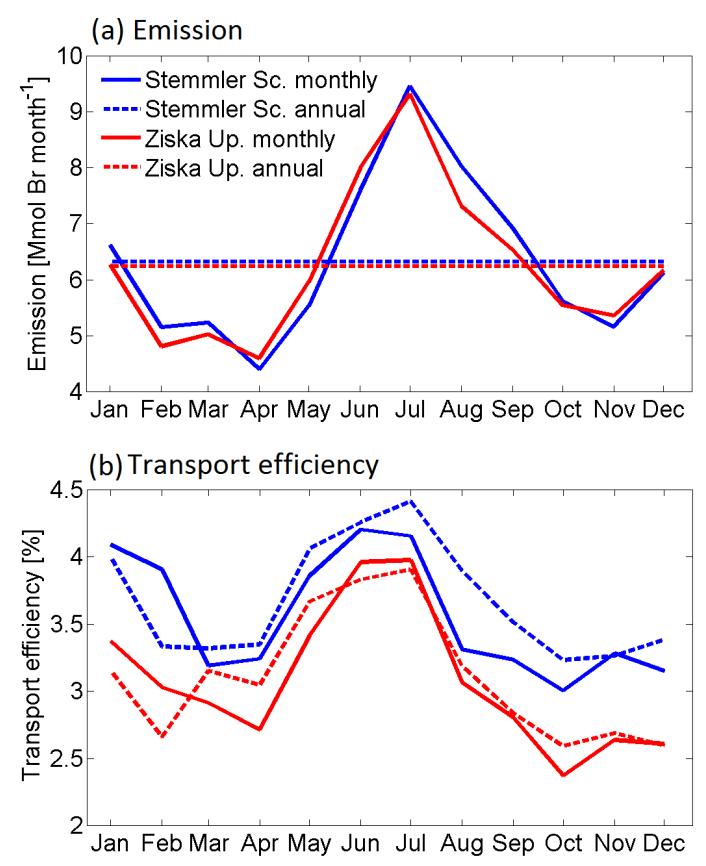

(c) Source gas injection

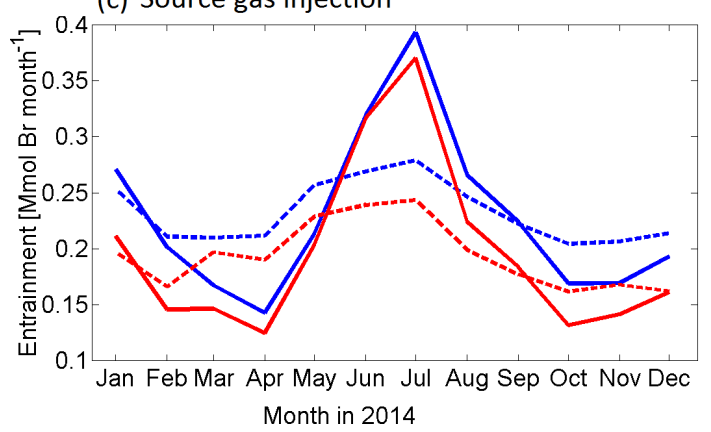

Figure 6. Annual cycles of monthly sums of bromoform (a) emission, (b) transport efficiency, and (c) source gas injection above the CPT in 2014 for the Ziska Updated and Stemmler Scaled monthly and annually averaged bromoform emission scenarios for the time of particle release.

averaged emissions lead to higher injection but lower VMRs than monthly averaged emissions. This will be discussed in Sect. 4.

\section{Discussion}

This study investigates the influences of monthly vs. annually averaged bromoform emission representation in transport modeling above the tropical Indian Ocean and west Pacific and its stratospheric injection. We found seasonal and spatial differences in the VMR at $17 \mathrm{~km}$ between monthly and annually averaged emissions. They can be explained by the annual cycle of emissions and transport above the Indian Ocean. In DJF, the monthly averaged emissions are as high as the annually averaged emissions (Fig. 6a), causing only small differences in VMR at the tropopause (Fig. 7c). In MAM, monthly averaged emissions are lower than annually averaged emissions (Fig. 6a), causing lower VMRs for monthly averaged than for annually averaged emissions in the central Indian Ocean (Fig. 7c). In JJA, monthly averaged emissions reach their maximum, which is approximately $50 \%$ (July) higher than the annually averaged emissions (Fig. 6a), and the transport efficiency through the Asian summer monsoon is also maximized (Fig. 6b), resulting in 50\% (July) more bromoform injection with monthly averaged emissions than with annually averaged emissions (Fig. 6c). Bromoform transported to the UTLS in boreal summer accumulates in the Asian monsoon anticyclone. The differing emission strength between annually and monthly averaged emissions causes a distinct signal in the difference of VMR at $17 \mathrm{~km}$ (Fig. 7c). In SON, the monthly averaged emissions are lower than the annually averaged emissions (Fig. 6a). However, we model higher VMRs around the CPT with monthly rather than with annually averaged emissions, (Fig. 7c), which we interpret as a signal carried to SON from the previous season. The lifetime of bromoform in the TTL is around 25 to 30 days (Hossaini et al., 2010), which could be long enough for it to accumulate in the Asian monsoon anticyclone and then be distributed across the Northern Hemisphere over Asia in SON. This spreading of air masses from the anticyclone across the Northern Hemisphere and also into the Southern Hemisphere during the breakup of the anticyclone in September has been observed for trace gases like $\mathrm{CO}, \mathrm{H}_{2} \mathrm{O}$, and $\mathrm{O}_{3}$ with satellites (Santee et al., 2017) and also simulated with a chemistry transport model (e.g., Vogel et al., 2016). Thus, the negative anomalies in the anticyclone in JJA (Fig. 7c) influence the UTLS region in SON, while the sign of the surface emission anomaly has already changed toward higher emissions from the annually rather than the monthly averaged emissions. Regarding the annual mean VMR of bromoform at the tropopause, the representation of monthly resolved emissions results in a shift of bromoform toward the Northern Hemisphere UTLS, especially to the Asian monsoon anticyclone, because of the different main injection seasons: JJA using monthly averaged emissions and MAM using annually averaged emissions. Especially for comparisons with observational data, it is essential to consider the pronounced annual cycle of VMRs over the Indian Ocean.

The distinct difference in atmospheric bromoform mixing ratios in the Asian summer monsoon anticyclone between the annual and monthly averaged emissions is also visible in the VMR profiles of this circulation regime (Fig. 3b). At the level of main convective outflow ( $\sim 14 \mathrm{~km})$, using monthly averaged bromoform emissions results in $50 \%$ higher mixing ratios than from annually averaged emissions. This large difference between the temporal distributions of emissions in a circulation regime with pronounced delivery to the stratosphere has a significant impact on stratospheric $\mathrm{Br}_{y}^{\mathrm{VSLS}}$ with $1.5 \mathrm{pptv}$ vs. 0.9 pptv source injections from bromoform monthly vs. annually averaged IO/WP emissions during the maximum in- 

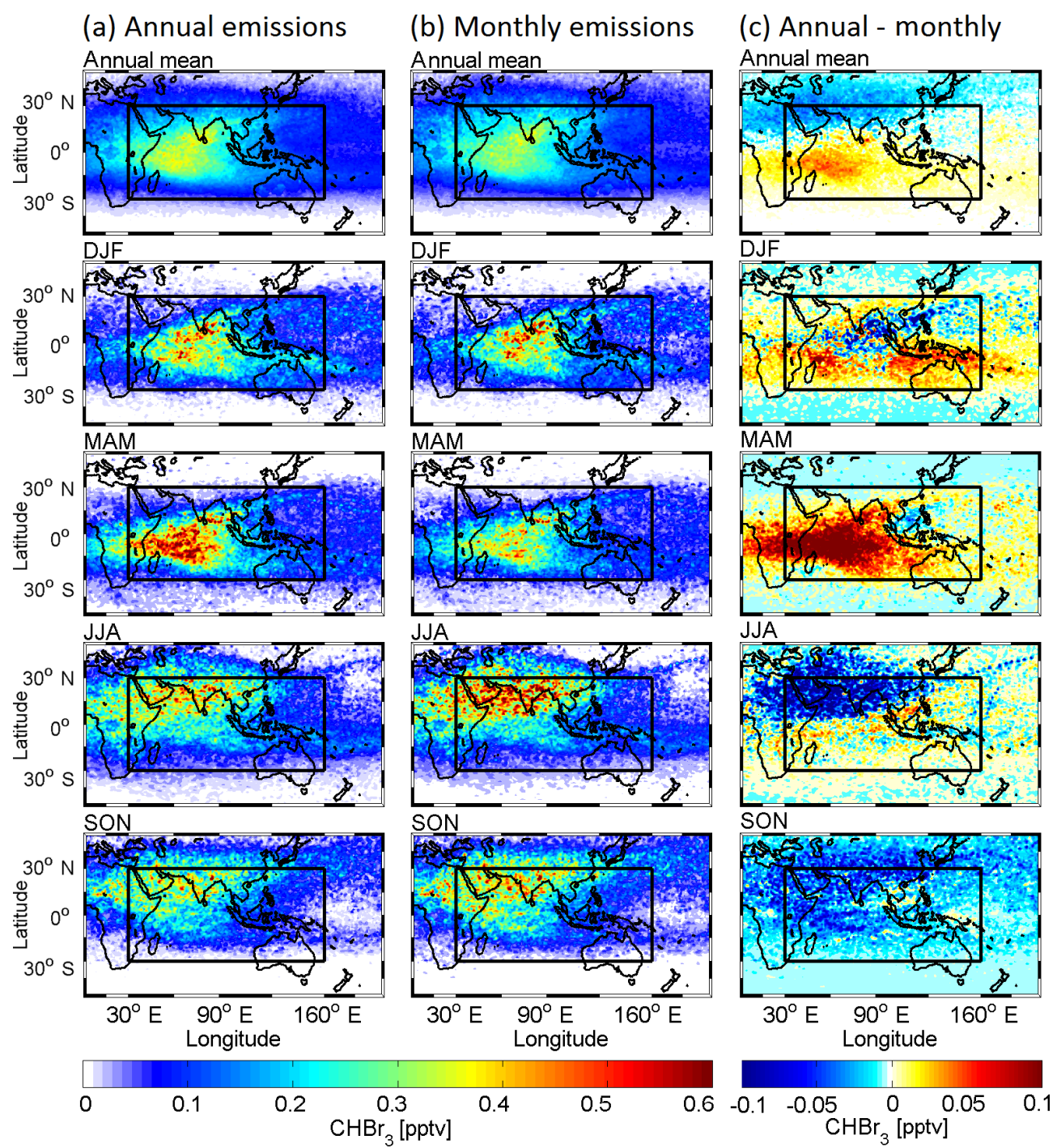

Figure 7. Bromoform volume mixing ratios (VMRs) at $17 \mathrm{~km}$ for the Ziska Updated (a) annually averaged emissions, (b) monthly averaged emissions, and (c) the difference between the two scenarios. The black box depicts the IO/WP release area.

jection season in boreal summer. Thus, we expect large seasonal differences for aircraft measurements of VSLS above the Asian summer monsoon region (Fig. 7).

Our results help to interpret the discrepancy of modeled seasonality of bromoform VMR in the UTLS between Liang et al. (2014) and Hossaini et al. (2016). Both studies use global emissions of bromoform and show results only for annual emission scenarios. While Liang et al. (2014) simulate the VMR maximum for bromoform above the tropical Indian Ocean during DJF using a chemistry climate model for 1960-2010, the set of chemistry climate and transport models for the period 1993-2012 from Hossaini et al. (2016) simulate the VMR maximum over the tropical west Pacific in DJF. They added that the contribution of the Asian monsoon pathway during JJA is highly uncertain, because of the wide spread in the signal from model to model. The importance of
DJF as a season of enhanced stratospheric injection is connected with the high transport efficiency above the tropical west Pacific during that season and, thus, also with the emissions of that region. The bromoform emissions inventory of Liang et al. (2010) used in Liang et al. (2014) has uniform high tropical emissions in the west and central Pacific, which are transported toward the Indian Ocean and Asian continent (their Fig. 7). The emission inventory of Ziska et al. (2013), which is shown for some models in Hossaini et al. (2016), has low emissions and even a sink in the northern tropical and subtropical west Pacific and high emissions in the tropical Indian Ocean, resulting in a weak maximum of bromoform VMR above the tropical west Pacific and Indian Ocean during JJA. We find in our study that the stratospheric injection seasonality depends on the seasonal and regional distribution of bromoform emissions from the IO/WP. Using seasonally 
varying oceanic bromoform emissions in our model simulations increases the importance of the JJA injection to the stratosphere through the Asian monsoon circulation.

\section{Uncertainties}

This study presents an estimate of bromoform injection to the stratosphere over the Indian Ocean and Asia. Uncertainties in the analysis result from the emission inventories and the FLEXPART model using ERA-Interim reanalysis fields.

The Ziska et al. (2013) bromoform emission inventory was updated in this study by including new observations. Available HalOcAt oceanic and atmospheric VSLS observations contain a mixture of data from different seasons and years, which are used to calculate concentration and mixing ratio climatologies. The seasonality in monthly averaged emissions from Ziska Updated results only from the seasonality in wind speed, and sea surface pressure used for the flux calculation, because the atmospheric and ocean concentrations are set constant throughout the year, due to the overall sparse data coverage, which does not allow a temporal resolution of the emissions. The Indian Ocean has a pronounced seasonality in ocean currents and upwelling regions (Schott et al., 2009) affecting the biological productivity, surface bromoform concentrations, and emissions (Quack et al., 2004; Hepach et al., 2015), which are not included in the Ziska calculations. Stemmler et al. (2015) include seasonality in the modeled oceanic bromoform concentrations from phytoplankton growth, assuming fixed production rates. This model study was designed to investigate processes that drive large-scale patterns of bromoform emissions from the open ocean and was carried out as a climatological steadystate simulation. Thus, deviations from observations arise, for example, through missing bromoform production from macroalgae along the coasts, fixed phytoplankton production rates, and unresolved temporal variability patterns caused, for example, by ENSO (Stemmler et al., 2015). Further differences in the spatial emission distribution between the two inventories result from limited available data for the Ziska climatology and from lacking sources and process understanding in the Stemmler climatology. One example is the data-based emission hot spot in the Bay of Bengal, which is not existent in the Stemmler inventory. MPIOM-HAMOCC results derived with the MPI-ESM were shown to be most realistic in the Indian Ocean compared to other CMIP5 models (Roxy et al., 2016). Furthermore, our Stemmler Scaled inventory uses a temporally and spatially uniform atmospheric bromoform mixing ratio to calculate the emissions. The annual cycle of emissions mainly results from the changes in surface wind speed for both inventories (Sect. 3.1). Thus, the annual cycle of oceanic concentrations plays a minor role in determining the annual emission cycle in the IO/WP region, but may become more important with higher resolution of the model and incorporation of coastal and open-ocean emission hot spot regions. Furthermore, the parameterization for the air-sea flux itself is estimated to introduce an uncertainty of a factor of 2 (Lennartz et al., 2015).

The emissions and transport of VSLSs in this study strongly depend on the ERA-Interim meteorological reanalysis and the boundary layer and convective parameterizations in the FLEXPART model. In most atmospheric models, convection, which occurs on scales smaller than the grid scale, is parameterized. The FLEXPART convection scheme was described and evaluated by Forster et al. (2007). FLEXPART ERA-Interim simulations have previously been used to diagnose the VSLS transport and good agreement with aircraft measurements of bromoform, dibromomethane, and methyl iodide up to $13 \mathrm{~km}$ above the tropical west Pacific (Fuhlbrügge et al., 2016) and methyl iodide in the UTLS (Tegtmeier et al., 2013) was achieved.

The total delivery of $\mathrm{Br}_{y}^{\mathrm{VSLS}}$ to the stratosphere, is made up by the oceanic source gases and their soluble product gases. The source gas injection into the stratosphere is generally enhanced with enhanced vertical uplift (Hossaini et al., 2010) and is overall estimated to contribute approximately half of the total stratospheric $\mathrm{Br}_{y}^{\mathrm{VSLS}}$ delivery of 2-8 pptv (Carpenter et al., 2014), with the other half coming from product gases. Here, we only consider source gas injection.

\section{Summary and conclusions}

For this study, we compiled two new bromoform emission inventories for the tropical Indian Ocean and west Pacific (IO/WP) in 2014: An update (this study) of the Ziska et al. (2013) inventory including new measurements in the west Indian Ocean (Fiehn et al., 2017) and an inventory using monthly surface water concentrations modeled by Stemmler et al. (2015) and scaled with measurements from the tropical Indian Ocean and west Pacific (this study). We calculated monthly emissions using climatological oceanic concentrations for Ziska Updated and monthly oceanic concentrations for Stemmler Scaled and fixed annual mean atmospheric mixing ratios and SST combined with monthly mean wind speed and sea level pressure data. The resulting seasonality in bromoform emissions in the tropical IO/WP is mainly driven by wind speed variations in the parameterized flux. The annual cycle of emissions for both inventories displays maximum emissions during boreal summer located in the Bay of Bengal, Arabian Sea, and the tropical southern Indian Ocean.

We modeled the ocean-to-stratosphere transport for 2014 with FLEXPART based on ERA-Interim fields using monthly and annually averaged bromoform emission scenarios for both inventories to detect the influence of seasonally varying emissions on stratospheric injection of VSLSs. A comparison of modeled bromoform with observations from aircraft and ship observations from the Indian Ocean, the South China Sea, and the west Pacific displays that modeled 
mixing ratios were generally lower than observations due to our regionally restricted model setup and, thus, missing oceanic sources further upwind from the central and east $\mathrm{Pa}$ cific Ocean and possibly too low emissions along the coasts and in the northwest Pacific.

The oceanic source regions for stratospheric bromoform and the injection regions to the stratosphere for monthly averaged emissions were analyzed. For both emission inventories, most stratospheric bromoform originates from the Arabian Sea and Bay of Bengal in boreal summer and from the tropical west Pacific in boreal winter. The main annual mean injection to the stratosphere occurs above the southern tip of India and results from the strong emissions from the Bay of Bengal and Arabian Sea and the efficient uplift with the Asian monsoon circulation during boreal summer.

We studied the influence of monthly resolved vs. annually averaged emission representation on the stratospheric injection and VMR of bromoform above the tropical IO/WP region in 2014. We simulated similar total annual bromoform delivery to the stratosphere whether applying monthly or annually averaged emissions. However, monthly averaged emissions lead to less injection above the Indian Ocean in boreal spring and more in boreal summer than annually averaged emissions. This causes up to $50 \%$ higher VMR in the Asian monsoon anticyclone and a change in the season with maximum VMR above the Indian Ocean at $17 \mathrm{~km}$ height. Annually averaged emissions lead to highest VMRs in MAM, while monthly averaged emissions cause highest VMR in JJA in the Asian monsoon anticyclone. The annual mean VMR at the tropopause using monthly averaged bromoform emissions are higher north of $15^{\circ} \mathrm{N}$ and lower around the equatorial and in the Southern Hemisphere than with annually averaged emissions, probably caused by the enhanced stratospheric injection through the Asian summer monsoon in the Northern Hemisphere.

Most surface-to-stratosphere transport above the Indian Ocean and Asia occurs in the Asian monsoon anticyclone during the summer monsoon and during its declining phase in boreal fall. The use of temporally constant bromoform emissions, a common practice of many chemistry transport and chemistry climate models (Warwick et al., 2006; Liang et al., 2014; Hossaini et al., 2016), significantly influences stratospheric delivery seasonally and regionally. This contributes to the large uncertainty in modeled VMRs and stratospheric source gas delivery of bromoform and, thus, the stratospheric bromine loading (Liang et al., 2014; Hossaini et al., 2016). Although the modeled total annual bromoform delivery to the stratosphere does not vary much between monthly and annually averaged emission inventories in our 2014 IO/WP study, the region and season of oceanic sources combined with effective atmospheric injection shifted the bromine pathway and seasonal and regional impact on the stratosphere. This is, in particular, of interest to future climate projections of stratospheric halogen loading with models projecting enhanced tropical deep convection (Hossaini et al., 2015) and a weakening Asian monsoon circulation (Christensen et al., 2013). This study was conducted for bromoform, but the impact of representing seasonally resolved oceanic emissions for delivery from the Indian Ocean to the stratosphere also applies for other oceanic VSLS with lifetimes in the range and shorter than bromoform. We therefore strongly recommend using seasonally and regionally resolved oceanic VSLS emissions in chemistry transport and chemistry climate models for process studies or comparisons to observations, in particular for the tropical Indian and west Pacific Ocean, as well as Asian monsoon regions.

Data availability. The updated Ziska bromoform emission inventory data are available at Pangaea and the FLEXPART model output is stored at UNINETT Sigma2 and can be inquired about by contacting the authors.

Supplement. The supplement related to this article is available online at: https://doi.org/10.5194/acp-18-11973-2018-supplement.

Author contributions. AF, KK, BQ, and IS designed the emission fields and the model experiments. AF carried out the FLEXPART calculations and the model analysis. FZ updated the Ziska et al. (2013) climatology for this study. AF and KK wrote the manuscript with contributions from all co-authors.

Competing interests. The authors declare that they have no conflict of interest.

Acknowledgements. Alina Fiehn was partly funded through the EU FP7 project StratoClim (603557). We thank the European Centre for Medium-Range Weather Forecasts (ECMWF) for the provision of ERA-Interim reanalysis data and the FLEXPART development team for the Lagrangian particle dispersion model used in this publication. The FLEXPART simulations were performed on resources provided by UNINETT Sigma2 - the National Infrastructure for High Performance Computing and Data Storage in Norway.

The article processing charges for this open-access publication were covered by a Research Centre of the Helmholtz Association.

Edited by: Rolf Müller

Reviewed by: Mengchu Tao and one anonymous referee

\section{References}

Aschmann, J., Sinnhuber, B.-M., Atlas, E. L., and Schauffler, S. M.: Modeling the transport of very short-lived substances into the tropical upper troposphere and lower stratosphere, Atmos. 
Chem. Phys., 9, 9237-9247, https://doi.org/10.5194/acp-9-92372009, 2009.

Aschmann, J., Sinnhuber, B.-M., Chipperfield, M. P., and Hossaini, R.: Impact of deep convection and dehydration on bromine loading in the upper troposphere and lower stratosphere, Atmos. Chem. Phys., 11, 2671-2687, https://doi.org/10.5194/acp11-2671-2011, 2011.

Aschmann, J. and Sinnhuber, B.-M.: Contribution of very shortlived substances to stratospheric bromine loading: uncertainties and constraints, Atmos. Chem. Phys., 13, 1203-1219, https://doi.org/10.5194/acp-13-1203-2013, 2013.

Butler, J. H., King, D. B., Lobert, J. M., Montzka, S. A., YvonLewis, S. A., Hall, B. D., Warwick, N. J., Mondeel, D. J., Aydin, M., and Elkins, J. W.: Oceanic distributions and emissions of short-lived halocarbons, Global Biogeochem. Cy., 21, GB1023, https://doi.org/10.1029/2006gb002732, 2007.

Carpenter, L. J. and Liss, P. S.: On temperate sources of bromoform and other reactive organic bromine gases, J. Geophys. Res.-Atmos., 105, 20539-20547, https://doi.org/10.1029/2000jd900242, 2000.

Carpenter, L. J., Sturges, W. T., Penkett, S. A., Liss, P. S., Alicke, B., Hebestreit, K., and Platt, U.: Short-lived alkyl iodides and bromides at Mace Head, Ireland: Links to biogenic sources and halogen oxide production, J. Geophys. Res.-Atmos., 104, 16791689, https://doi.org/10.1029/98jd02746, 1999.

Carpenter, L. J., Reimann, S., Burkholder, J. B., Clerbaux, C., Hall, B. D., Hossaini, R., Laube, J. C., and Yvon-Lewis, S. A.: Ozone-Depleting Substances (ODSs) and other gases of interest to the Montreal Protocol, in: Scientific Assessment of Ozone Depletion: 2014, Global Ozone Research and monitoring Project - Report N. 55, World Meteorological Organization, Geneva, Switzerland, 2014.

Christensen, J. H., Kumar, K. K., Aldrian, E., An, S.-I., Cavalcanti, I. F. A., Castro, M. D., Dong, W., Goswami, P., Hall, A., Kanyanga, J. K., Kitoh, A., Kossin, J., Lau, N.-C., Renwick, J., Stephenson, D. B., Xie, S.-P., and Zhou, T.: Climate Phenomena and their Relevance for Future Regional Climate Change, Climate Change 2013: The Physical Science Basis. Contribution of Working Group I to the Fifth Assessment Report of the Intergovernmental Panel on Climate Change, edited by: Stocker, T. F., Qin, D., Plattner, G.-K., Tignor, M., Allen, S. K., Boschung, J., Nauels, A., Xia, Y., Bex, V., and Midgley, P. M., Cambridge University Press, Cambridge, United Kingdom and New York, NY, USA, 2013.

Dee, D. P., Uppala, S. M., Simmons, A. J., Berrisford, P., Poli, P., Kobayashi, S., Andrae, U., Balmaseda, M. A., Balsamo, G., Bauer, P., Bechtold, P., Beljaars, A. C. M., van de Berg, L., Bidlot, J., Bormann, N., Delsol, C., Dragani, R., Fuentes, M., Geer, A. J., Haimberger, L., Healy, S. B., Hersbach, H., Hólm, E. V., Isaksen, L., Kållberg, P., Köhler, M., Matricardi, M., McNally, A. P., Monge-Sanz, B. M., Morcrette, J. J., Park, B. K., Peubey, C., de Rosnay, P., Tavolato, C., Thépaut, J. N., and Vitart, F.: The ERA-Interim reanalysis: configuration and performance of the data assimilation system, Q. J. Roy. Meteor. Soc., 137, 553-597, https://doi.org/10.1002/qj.828, 2011.

Dorf, M., Butler, J. H., Butz, A., Camy-Peyret, C., Chipperfield, M. P., Kritten, L., Montzka, S. A., Simmes, B., Weidner, F., and Pfeilsticker, K.: Long-term observations of stratospheric bromine reveal slow down in growth, Geophys. Res. Lett., 33, L24803, https://doi.org/10.1029/2006g1027714, 2006.

Dvortsov, V. L., Geller, M. A., Solomon, S., Schauffler, S. M., Atlas, E. L., and Blake, D. R.: Rethinking reactive halogen budgets in the midlatitude lower stratosphere, Geophys. Res. Lett., 26, 1699-1702, https://doi.org/10.1029/1999g1900309, 1999.

Fiehn, A., Quack, B., Hepach, H., Fuhlbrügge, S., Tegtmeier, S., Toohey, M., Atlas, E., and Krüger, K.: Delivery of halogenated very short-lived substances from the west Indian Ocean to the stratosphere during the Asian summer monsoon, Atmos. Chem. Phys., 17, 6723-6741, https://doi.org/10.5194/acp17-6723-2017, 2017.

Fiehn, A., Quack, B., Marandino, C. A., and Krüger, K.: Transport Variability of Very Short Lived Substances From the West Indian Ocean to the Stratosphere, J. Geophy. Res.-Atmos., 123, 57205738, https://doi.org/10.1029/2017JD027563, 2018.

Forster, C., Stohl, A., and Seibert, P.: Parameterization of convective transport in a Lagrangian particle dispersion model and its evaluation, J. Appl. Meteorol. Clim., 46, 403-422, https://doi.org/10.1175/JAM2470.1, 2007.

Fuhlbrügge, S., Quack, B., Tegtmeier, S., Atlas, E., Hepach, H., Shi, Q., Raimund, S., and Krüger, K.: The contribution of oceanic halocarbons to marine and free tropospheric air over the tropical West Pacific, Atmos. Chem. Phys., 16, 7569-7585, https://doi.org/10.5194/acp-16-7569-2016, 2016.

Gettelman, A., Lauritzen, P. H., Park, M., and Kay, J. E.: Processes regulating short-lived species in the tropical tropopause layer, J. Geophys. Res.-Atmos., 114, D13303, https://doi.org/10.1029/2009jd011785, 2009.

Gottschaldt, K.-D., Schlager, H., Baumann, R., Bozem, H., Eyring, V., Hoor, P., Jöckel, P., Jurkat, T., Voigt, C., Zahn, A., and Ziereis, H.: Trace gas composition in the Asian summer monsoon anticyclone: a case study based on aircraft observations and model simulations, Atmos. Chem. Phys., 17, 6091-6111, https://doi.org/10.5194/acp-17-6091-2017, 2017.

Hense, I. and Quack, B.: Modelling the vertical distribution of bromoform in the upper water column of the tropical Atlantic Ocean, Biogeosciences, 6, 535-544, https://doi.org/10.5194/bg-6-5352009, 2009.

Hepach, H., Quack, B., Raimund, S., Fischer, T., Atlas, E. L., and Bracher, A.: Halocarbon emissions and sources in the equatorial Atlantic Cold Tongue, Biogeosciences, 12, 6369-6387, https://doi.org/10.5194/bg-12-6369-2015, 2015.

Hossaini, R., Chipperfield, M. P., Monge-Sanz, B. M., Richards, N. A. D., Atlas, E., and Blake, D. R.: Bromoform and dibromomethane in the tropics: a 3-D model study of chemistry and transport, Atmos. Chem. Phys., 10, 719-735, https://doi.org/10.5194/acp-10-719-2010, 2010.

Hossaini, R., Chipperfield, M. P., Feng, W., Breider, T. J., Atlas, E., Montzka, S. A., Miller, B. R., Moore, F., and Elkins, J.: The contribution of natural and anthropogenic very short-lived species to stratospheric bromine, Atmos. Chem. Phys., 12, 371380, https://doi.org/10.5194/acp-12-371-2012, 2012.

Hossaini, R., Mantle, H., Chipperfield, M. P., Montzka, S. A., Hamer, P., Ziska, F., Quack, B., Krüger, K., Tegtmeier, S., Atlas, E., Sala, S., Engel, A., Bönisch, H., Keber, T., Oram, D., Mills, G., Ordóñez, C., Saiz-Lopez, A., Warwick, N., Liang, Q., Feng, W., Moore, F., Miller, B. R., Marécal, V., Richards, N. A. D., Dorf, M., and Pfeilsticker, K.: Evaluating global 
emission inventories of biogenic bromocarbons, Atmos. Chem. Phys., 13, 11819-11838, https://doi.org/10.5194/acp-13-118192013, 2013.

Hossaini, R., Chipperfield, M. P., Montzka, S. A., Rap, A., Dhomse, S., and Feng, W.: Efficiency of short-lived halogens at influencing climate through depletion of stratospheric ozone, Nat. Geosci., 8, 186-190, https://doi.org/10.1038/ngeo2363, 2015.

Hossaini, R., Patra, P. K., Leeson, A. A., Krysztofiak, G., Abraham, N. L., Andrews, S. J., Archibald, A. T., Aschmann, J., Atlas, E. L., Belikov, D. A., Bönisch, H., Carpenter, L. J., Dhomse, S., Dorf, M., Engel, A., Feng, W., Fuhlbrügge, S., Griffiths, P. T., Harris, N. R. P., Hommel, R., Keber, T., Krüger, K., Lennartz, S. T., Maksyutov, S., Mantle, H., Mills, G. P., Miller, B., Montzka, S. A., Moore, F., Navarro, M. A., Oram, D. E., Pfeilsticker, K., Pyle, J. A., Quack, B., Robinson, A. D., Saikawa, E., Saiz-Lopez, A., Sala, S., Sinnhuber, B.-M., Taguchi, S., Tegtmeier, S., Lidster, R. T., Wilson, C., and Ziska, F.: A multi-model intercomparison of halogenated very shortlived substances (TransCom-VSLS): linking oceanic emissions and tropospheric transport for a reconciled estimate of the stratospheric source gas injection of bromine, Atmos. Chem. Phys., 16, 9163-9187, https://doi.org/10.5194/acp-16-9163-2016, 2016.

Ilyina, T., Six, K. D., Segschneider, J., Maier-Reimer, E., Li, H., and Núñez-Riboni, I.: Global ocean biogeochemistry model HAMOCC: Model architecture and performance as component of the MPI-Earth system model in different CMIP5 experimental realizations, J. Adv. Model. Earth Sy., 5, 287-315, https://doi.org/10.1029/2012ms000178, 2013.

Krüger, K. and Quack, B.: Introduction to special issue: the TransBrom Sonne expedition in the tropical West Pacific, Atmos. Chem. Phys., 13, 9439-9446, https://doi.org/10.5194/acp-139439-2013, 2013.

Law, K. S., Sturges, W. T., Blake, D. R., Blake, N. J., Burkeholder, J. B., Butler, J. H., Cox, R. A., Haynes, P. H., Ko, M. K. W., Kreher, K., Mari, C., Pfeilsticker, K., Plane, J. M. C., Salawitch, R. J., Schiller, C., Sinnhuber, B. M., von Glasow, R., Warwick, N. J., Wuebbles, D. J., and Yvon-Lewis, S. A.: Halogenated Very Short-Lived Substances, in: Scientific Assessment of Ozone Depletion: 2006, Global Ozone Research and Monitoring Project - Report N. 50, World Meteorological Organization, Geneva, Switzerland, 2006.

Lennartz, S. T., Krysztofiak, G., Marandino, C. A., Sinnhuber, B.M., Tegtmeier, S., Ziska, F., Hossaini, R., Krüger, K., Montzka, S. A., Atlas, E., Oram, D. E., Keber, T., Bïnisch, H., and Quack, B.: Modelling marine emissions and atmospheric distributions of halocarbons and dimethyl sulfide: the influence of prescribed water concentration vs. prescribed emissions, Atmos. Chem. Phys., 15, 11753-11772, https://doi.org/10.5194/acp-15-11753$2015,2015$.

Liang, Q., Stolarski, R. S., Kawa, S. R., Nielsen, J. E., Douglass, A. R., Rodriguez, J. M., Blake, D. R., Atlas, E. L., and Ott, L. E.: Finding the missing stratospheric Bry: a global modeling study of $\mathrm{CHBr}_{3}$ and $\mathrm{CH}_{2} \mathrm{Br}_{2}$, Atmos. Chem. Phys., 10, 2269-2286, https://doi.org/10.5194/acp-10-2269-2010, 2010.

Liang, Q., Atlas, E., Blake, D., Dorf, M., Pfeilsticker, K., and Schauffler, S.: Convective transport of very short lived bromocarbons to the stratosphere, Atmos. Chem. Phys., 14, 5781-5792, https://doi.org/10.5194/acp-14-5781-2014, 2014.
Montzka, S., Reimann, S., Engel, A., Kruger, K., Sturges, W., Blake, D., Dorf, M., Fraser, P., Froidevaux, L., and Jucks, K.: Scientific assessment of ozone depletion: 2010, Global Ozone Research and Monitoring Project-Report No. 51, 2010.

Morgenstern, O., Hegglin, M. I., Rozanov, E., O’Connor, F. M., Abraham, N. L., Akiyoshi, H., Archibald, A. T., Bekki, S., Butchart, N., Chipperfield, M. P., Deushi, M., Dhomse, S. S., Garcia, R. R., Hardiman, S. C., Horowitz, L. W., Jöckel, P., Josse, B., Kinnison, D., Lin, M., Mancini, E., Manyin, M. E., Marchand, M., Marécal, V., Michou, M., Oman, L. D., Pitari, G., Plummer, D. A., Revell, L. E., Saint-Martin, D., Schofield, R., Stenke, A., Stone, K., Sudo, K., Tanaka, T. Y., Tilmes, S., Yamashita, Y., Yoshida, K., and Zeng, G.: Review of the global models used within phase 1 of the Chemistry-Climate Model Initiative (CCMI), Geosci. Model Dev., 10, 639-671, https://doi.org/10.5194/gmd-10-639-2017, 2017.

Munchak, L. A. and Pan, L. L.: Separation of the lapse rate and the cold point tropopauses in the tropics and the resulting impact on cloud top-tropopause relationships, J. Geophys. Res.-Atmos., 119, 7963-7978, https://doi.org/10.1002/2013jd021189, 2014.

Newell, R. E. and Gould-Stewart, S.: A Stratospheric Fountain?, J. Atmos. Sci., 38, 2789-2796, https://doi.org/10.1175/15200469(1981)038<2789:ASF>2.0.CO;2, 1981.

Nielsen, J. E. and Douglass, A. R.: A simulation of bromoform's contribution to stratospheric bromine, J. Geophys. Res., 106, 8089-8100, https://doi.org/10.1029/2000JD900767, 2001.

Nightingale, P., Malin, G., Law, C., Watson, A., Liss, P., Liddicoat, M., Boutin, J., and Upstill-Goddard, R.: In situ evaluation of air-sea gas exchange parameterizations using novel conservative and volatile tracers, Global Biogeochem. Cy., 14, 373-387, https://doi.org/10.1029/1999GB900091, 2000.

Orbe, C., Waugh, D. W., and Newman, P. A.: Air-mass origin in the tropical lower stratosphere: The influence of Asian boundary layer air, Geophys. Res. Lett., 42, 4240-4248, https://doi.org/10.1002/2015g1063937, 2015.

Ordóñez, C., Lamarque, J.-F., Tilmes, S., Kinnison, D. E., Atlas, E. L., Blake, D. R., Sousa Santos, G., Brasseur, G., and Saiz-Lopez, A.: Bromine and iodine chemistry in a global chemistry-climate model: description and evaluation of very short-lived oceanic sources, Atmos. Chem. Phys., 12, 14231447, https://doi.org/10.5194/acp-12-1423-2012, 2012.

Palmer, C. J. and Reason, C. J.: Relationships of surface bromoform concentrations with mixed layer depth and salinity in the tropical oceans, Global Biogeochem. Cy., 23, GB2014, https://doi.org/10.1029/2008gb003338, 2009.

Pisso, I., Haynes, P. H., and Law, K. S.: Emission location dependent ozone depletion potentials for very short-lived halogenated species, Atmos. Chem. Phys., 10, 12025-12036, https://doi.org/10.5194/acp-10-12025-2010, 2010.

Quack, B. and Wallace, D. W. R.: Air-sea flux of bromoform: Controls, rates, and implications, Global Biogeochem. Cy., 17, 1023, https://doi.org/10.1029/2002gb001890, 2003.

Quack, B., Atlas, E., Petrick, G., Stroud, V., Schauffler, S., and Wallace, D. W. R.: Oceanic bromoform sources for the tropical atmosphere, Geophys. Res. Lett., 31, L23S05, https://doi.org/10.1029/2004g1020597, 2004.

Quack, B., Atlas, E., Petrick, G., and Wallace, D. W. R.: Bromoform and dibromomethane above the Mauritanian upwelling: At- 
mospheric distributions and oceanic emissions, J. Geophys. Res., 112, D09312, https://doi.org/10.1029/2006jd007614, 2007.

Randel, W. J., Park, M., Emmons, L., Kinnison, D., Bernath, P., Walker, K. A., Boone, C., and Pumphrey, H.: Asian monsoon transport of pollution to the stratosphere, Science, 328, 611-613, https://doi.org/10.1126/science.1182274, 2010.

Roxy, Modi, A., Murtugudde, R., Valsala, V., Panickal, S., Prasanna Kumar, S., Ravichandran, M., Vichi, M., and Lévy, M.: A reduction in marine primary productivity driven by rapid warming over the tropical Indian Ocean, Geophys. Res. Lett., 43, 826-833, https://doi.org/10.1002/2015gl066979, 2016.

Roy, R., Pratihary, A., Narvenkar, G., Mochemadkar, S., Gauns, M., and Naqvi, S. W. A.: The relationship between volatile halocarbons and phytoplankton pigments during a Trichodesmium bloom in the coastal eastern Arabian Sea, Estuar. Coast. Shelf S., 95, 110-118, https://doi.org/10.1016/j.ecss.2011.08.025, 2011.

Santee, M. L., Manney, G. L., Livesey, N. J., Schwartz, M. J., Neu, J. L., and Read, W. G.: A comprehensive overview of the climatological composition of the Asian summer monsoon anticyclone based on 10 years of Aura Microwave Limb Sounder measurements, J. Geophys. Res.-Atmos., 122, 54915514, https://doi.org/10.1002/2016jd026408, 2017.

Schott, F. A., Xie, S.-P., and McCreary, J. P.: Indian Ocean circulation and climate variability, Rev. Geophys., 47, RG1002, https://doi.org/10.1029/2007rg000245, 2009.

Stemmler, I., Hense, I., and Quack, B.: Marine sources of bromoform in the global open ocean - global patterns and emissions, Biogeosciences, 12, 1967-1981, https://doi.org/10.5194/bg-121967-2015, 2015.

Stohl, A. and Thomson, D.: A density correction for Lagrangian particle dispersion models, Bound.-Lay. Meteorol., 90, 155-167, https://doi.org/10.1023/A:1001741110696, 1999.

Stohl, A. and Trickl, T.: A textbook example of long-range transport: Simultaneous observation of ozone maxima of stratospheric and North American origin in the free troposphere over Europe, J. Geophys. Res.-Atmos., 104, 30445-30462, https://doi.org/10.1029/1999JD900803, 1999.

Stohl, A., Hittenberger, M., and Wotawa, G.: Validation of the Lagrangian particle dispersion model FLEXPART against largescale tracer experiment data, Atmos. Environ., 32, 4245-4264, https://doi.org/10.1016/S1352-2310(98)00184-8, 1998.

Stohl, A., Forster, C., Frank, A., Seibert, P., and Wotawa, G.: Technical note: The Lagrangian particle dispersion model FLEXPART version 6.2, Atmos. Chem. Phys., 5, 2461-2474, https://doi.org/10.5194/acp-5-2461-2005, 2005.

Tegtmeier, S., Krüger, K., Quack, B., Atlas, E. L., Pisso, I., Stohl, A., and Yang, X.: Emission and transport of bromocarbons: from the West Pacific ocean into the stratosphere, Atmos. Chem. Phys., 12, 10633-10648, https://doi.org/10.5194/acp-12-106332012, 2012.

Tegtmeier, S., Krüger, K., Quack, B., Atlas, E., Blake, D. R., Boenisch, H., Engel, A., Hepach, H., Hossaini, R., Navarro, M. A., Raimund, S., Sala, S., Shi, Q., and Ziska, F.: The contribution of oceanic methyl iodide to stratospheric iodine, Atmos. Chem. Phys., 13, 11869-11886, https://doi.org/10.5194/acp-13-118692013, 2013.
Tegtmeier, S., Ziska, F., Pisso, I., Quack, B., Velders, G. J. M., Yang, X., and Krüger, K.: Oceanic bromoform emissions weighted by their ozone depletion potential, Atmos. Chem. Phys., 15, 1364713663, https://doi.org/10.5194/acp-15-13647-2015, 2015.

Tissier, A.-S. and Legras, B.: Convective sources of trajectories traversing the tropical tropopause layer, Atmos. Chem. Phys., 16, 3383-3398, https://doi.org/10.5194/acp-16-3383-2016, 2016.

Vogel, B., Günther, G., Müller, R., Grooß, J.-U., and Riese, M.: Impact of different Asian source regions on the composition of the Asian monsoon anticyclone and of the extratropical lowermost stratosphere, Atmos. Chem. Phys., 15, 13699-13716, https://doi.org/10.5194/acp-15-13699-2015, 2015.

Vogel, B., Günther, G., Müller, R., Grooß, J.-U., Afchine, A., Bozem, H., Hoor, P., Krämer, M., Müller, S., Riese, M., Rolf, C., Spelten, N., Stiller, G. P., Ungermann, J., and Zahn, A.: Longrange transport pathways of tropospheric source gases originating in Asia into the northern lower stratosphere during the Asian monsoon season 2012, Atmos. Chem. Phys., 16, 15301-15325, https://doi.org/10.5194/acp-16-15301-2016, 2016.

Warwick, N. J., Pyle, J. A., Carver, G. D., Yang, X., Savage, N. H., O'Connor, F. M., and Cox, R. A.: Global modeling of biogenic bromocarbons, J. Geophys. Res.-Atmos., 111, D24305, https://doi.org/10.1029/2006jd007264, 2006.

Wisher, A., Oram, D. E., Laube, J. C., Mills, G. P., van Velthoven, P., Zahn, A., and Brenninkmeijer, C. A. M.: Very short-lived bromomethanes measured by the CARIBIC observatory over the North Atlantic, Africa and Southeast Asia during 2009-2013, Atmos. Chem. Phys., 14, 3557-3570, https://doi.org/10.5194/acp14-3557-2014, 2014.

Yamamoto, H., Yokouchi, Y., Otsuki, A., and Itoh, H.: Depth profiles of volatile halogenated hydrocarbons in seawater in the Bay of Bengal, Chemosphere, 45, 371-377, https://doi.org/10.1016/S0045-6535(00)00541-5, 2001.

Ziska, F., Quack, B., Abrahamsson, K., Archer, S. D., Atlas, E., Bell, T., Butler, J. H., Carpenter, L. J., Jones, C. E., Harris, N. R. P., Hepach, H., Heumann, K. G., Hughes, C., Kuss, J., Krüger, K., Liss, P., Moore, R. M., Orlikowska, A., Raimund, S., Reeves, C. E., Reifenhäuser, W., Robinson, A. D., Schall, C., Tanhua, T., Tegtmeier, S., Turner, S., Wang, L., Wallace, D., Williams, J., Yamamoto, H., Yvon-Lewis, S., and Yokouchi, Y.: Global sea-to-air flux climatology for bromoform, dibromomethane and methyl iodide, Atmos. Chem. Phys., 13, 89158934, https://doi.org/10.5194/acp-13-8915-2013, 2013. 